\title{
Los hijos de las tinieblas son más sagaces que los hijos de la luz. Pensamiento político católico y marxismo en Chile, 1960-1964
}

\author{
The children of darkness are wiser than the children of light. Catholic \\ politician and Marxist thought in Chile, 1960-1964
}

Marcos Fernández Labbé*

\begin{abstract}
Resumen
El presente artículo busca reconstituir e interpretar históricamente los argumentos elaborados por el pensamiento católico chileno para articular una posición anticomunista entre inicios de 1960 y las elecciones de 1964. Esta posición varío entre posiciones tradicionales, la apertura al diálogo y el rechazo estratégico en función de privilegiar la opción demócrata cristiana. A partir de lo anterior se concluye tanto la relevancia del anticomunismo como factor de cohesión al interior del pensamiento católico, como su eficiencia en la constitución del campo político chileno del periodo.
\end{abstract}

Palabras Clave: Anticomunismo, Pensamiento Católico, Iglesia Católica, Historia Política, Marxismo, Historia de Chile

\begin{abstract}
This article interpreted the arguments used by Catholic thought to build an anticommunist position in Chile in early 1960. Its review different discussions and justifications that shaped like the traditional anti-communist alternatives, the Social Christianity turn and the intensification of the confrontation between Marxism and Catholicism on the eve of the presidential elections of 1964. It concludes by highlighting the centrality of anti - communism as a factor of cohesion of Catholic thought, and its importance in shaping the contemporary political arena.
\end{abstract}

Keywords: Anti-Communism, Catholic Thought, Catholic Church, Political History, Marxism, Chilean History.

\footnotetext{
${ }^{*}$ Chileno, Doctor en Historia, Departamento de Historia Universidad Alberto Hurtado. Este artículo es parte de una investigación mayor financiada por el proyecto Fondecyt Regular "De la Reforma a la Solidaridad: vocabulario político-conceptual de la Iglesia Católica chilena, 1960-1985". Su realización ha sido posible gracias a la colaboración de personas e instituciones a las que quisiera agradecer. Como ayudantes de investigación participaron en la recopilación de los materiales que informan el texto Daniela Belmar, Pablo Geraldo, Javiera Letelier y Matías Placencio. El análisis y complemento de la documentación fue facilitado por estadías de investigación en el Centre for the Study of Religion and Politics de la University of St Andrews, la Biblioteca del Instituto Iberoamericano de Berlín y en la Pontificia Universidad Javeriana de Bogotá. Del mismo modo, quiero agradecer especialmente a todos aquellos que trabajan en la Biblioteca de la Facultad de Teología de la Pontificia Universidad Católica de Chile por su siempre excelente disposición. mfernand@uahurtado.cl
} 


\section{Introducción}

\section{Antagonismo, conceptualidad y anticomunismo: breve síntesis teórico- historiográfica.}

Uno de los asertos analíticamente más fértiles de la Historia Conceptual es aquel que hace referencia al proceso de politización de los conceptos, es decir, al hecho de que al momento de insertarse en un campo de significados políticos, un concepto aligera su carga descriptiva de la realidad y tiende a subrayar una función más cercana al arma de combate, en tanto su utilización es gobernada por el ánimo de la polémica, la controversia, la injuria o la sola descalificación, útil para destacar las virtudes del concepto definido como antagónico. En la lógica de la semantización histórica a la que están sujetos los componentes de un determinado vocabulario político, la recurrencia de los procesos de politización estará dada por coyunturas de enfrentamiento, diferenciación y surgimiento de proposiciones políticas que compitan por una posición en el campo político en cuestión, produciendo con ello procesos de articulación que permitan a la red conceptual de un determinado discurso el hacerse un espacio en dicho campo mediante la puesta en común de significados y por ello, de oposiciones y referencialidades explicitas.

De esa forma, la función del antagonismo que la politización conceptual supone aparece como un muy eficiente mecanismo de construcción de significados a la vez que una estrategia de cohesión política eficaz, en tanto permite a los agentes que participan de la red conceptual construida antagónicamente dejar de lado otro tipo de diferencias y fortalecerse en los factores que poseen en comunidad. El concepto politizado no busca describir al fenómeno al que hace referencia ni a su historicidad, sino que modelarlo de acuerdo a las necesidades, por un lado, de su propia articulación en un campo de significados previo; y por otro a la definición de criterios de cohesión que favorezcan a sus propios agentes. Así, el referente efectivo del concepto politizado es desechado en su fisonomía real, asignándosele -siempre en la lógica del antagonismo- una singular versatilidad, en tanto debe ser capaz de dar cuenta de los temores, antinomias e inversiones semánticas del discurso que se le enfrenta. ${ }^{1}$

Un caso particularmente ilustrativo de la operación conceptual antes reseñada es el del anticomunismo así en Chile como en América Latina, en tanto que una breve revisión por la serie de investigaciones históricas que han buscado abordarlo llegan a conclusiones muy

\footnotetext{
${ }^{1}$ Esta proposición teórico-metodológica para enfrentar el análisis que sigue es deudora de tres enfoques centrales: aquel relacionado con la Historia Conceptual (Begriffsgeschichte), el propuesto por la Historia PostSocial y las nociones de articulación y antagonismo desarrolladas por Chantal Mouffe y Ernesto Laclau. Textos de referencia de este tipo de enfoques son: ReinhardtKoselleck "Introducción al Diccionario Histórico de conceptos político-sociales básicos en lengua alemana”,Anthropos, 223, Barcelona, 1999, pp.333-358; H.E. Bodeker, "Sobre el perfil metodológico de la historia conceptual”,Historia y Grafía, 32, México, 2009, pp. 131-168; Ch. Mouffe y E. Laclau, Hegemonia y estrategia socialista. Hacia una radicalización de la democracia, Buenos Aires, FCE, 2004, pp. 129-189;M.A. Cabrera,Historia, Lenguaje y Teoría de la Sociedad, Valencia,Frónesis, 2001, pp. 47-66.
} 
similares: por un lado, el carácter ideológico del fenómeno de construcción del anticomunismo, entendido así como un recurso útil para justificar prácticas de autoritarismo y represión contra los agentes sindicados como "comunistas", como su naturaleza de "entidad fantasmática omnipresente", y por ello ineludible para la organización y cohesión de fuerzas políticas contrarias al comunismo. ${ }^{3}$ En tal sentido, es ilustrativa la imagen de "gramática común" a la que aluden Bohoslavsky y Vicente para describir el comportamiento de las distintas familias del anticomunismo en Argentina-la católicanacionalista, la liberal-conservadora y la autoritaria-estatista -, en términos de que independientemente de sus matices singulares, encontraban un foco de acción y de construcción significativa en su oposición al comunismo. ${ }^{4}$

A partir de este tipo de supuestos, la historiografía regional en torno al anticomunismo es breve y reciente, y se ha desenvuelto a la luz tanto de la periodificación y tematización referida a la Guerra Fría, como al "retorno" analítico hacia la historización de las derechas latinoamericanas. ${ }^{5}$ En una rápida síntesis, lo que algunos de estos trabajos logran definir son tanto los espacios de desenvolvimiento de los discursos y las prácticas anticomunistas (los partidos de derecha, las universidades, organizaciones nacionalistas y patronales, las Fuerzas Armadas, el catolicismo y los medios de divulgación propios de la cultura de masas) como sus motivaciones esenciales: el temor a la infiltración comunista en todos los espacios de la sociedad, el predominio del ateísmo y el colectivismo, la disolución moral y la destrucción de la familia, el imperialismo soviético, el descontrol de las clases obreras, la persecución contra la Iglesia Católica, la crítica a los partidos políticos tradicionales y al sistema democrático en su conjunto por su incapacidad para contener el avance comunista, la vulneración del derecho de propiedad y la amenaza de la violencia revolucionaria. ${ }^{6}$

\footnotetext{
2 Alfredo Riquelme S., Rojo atardecer. El comunismo chileno entre dictadura y democracia, Santiago, CIDBA, 2009, p. 38.

${ }^{3}$ Elena Scirica, "Introducción Dossier Comunistas y anticomunistas en la Argentina. Agrupaciones, redes e iniciativas políticas y culturales en el marco de la Guerra Fría en América Latina (circa 1960)",Anuario del Instituto de Historia Argentina, 14, Buenos Aires, 2014, p. 2.

4 Ernesto Bohoslavsky y Martín Vicente, "Sino el espanto". Temas, prácticas y alianzas de los anticomunismos de derecha en Argentina entre 1955 y 1966",Anuario del Instituto de Historia Argentina, Buenos Aires, 14, 2014, p. 3.

${ }^{5}$ TanyaHarmer, El gobierno de Allende y la Guerra fría interamericana, Santiago, Ediciones UDP, 2013; TanyaHarmer y Alfredo Riquelme S., Chile y la Guerra Fría global, Santiago, Instituto de Historia UC-RIL editores, 2014; Sandra McGee Deutsch, Las derechas. La extrema derecha en Argentina, Brasil y Chile, 1890-1939, Buenos Aires, Universidad de Quilmes, 2005.

${ }^{6}$ IankoBett, "Catolicismo e Cruzada e a sociabilidadeanticomunista na década de 1960”,C. Rodrigues, G. Zanotto y R. CoppeCaldeira (editores), Manifestacoes do pensamento católico na América do Sul, Rio Grande do Sul, Fonte-FAPERGS, 2015, pp. 233-258; Ernesto Bohoslavsky y Martín Vicente, op. cit, passim; Magdalena Broquetas, "Los frentes del anticomunismo. Las derechas en el Uruguay de los tempranos sesenta", Contemporánea, 3/3, Montevideo, 2012, pp. 11-29; Gabriel Bucheli, "Organizaciones "demócratas" y radicalización anticomunista en Uruguay, 1959-1962”, Contemporánea, 3/3, Montevideo, 2012, pp. 31-52; Marcelo Casals, "Chile en la encrucijada". Anticomunismo y propaganda en la "campaña del terror" de las elecciones presidenciales de 1964", en TanyaHarmer y Alfredo Riquelme S. (editores),op. cit., pp. 89-111; Rodrigo PattoSá Motta, Em guarda contra o “perigovermelho”: O anticomunismo no Brasil (1917-1964),
} 
En el caso específico de Chile, sin dudas que la investigación más detallada y lúcida en torno al fenómeno es la llevada a cabo por Marcelo Casals, quien a lo largo de las páginas de su tesis de Magíster en Historia por la Pontificia Universidad Católica de Chile logra dar cuenta de los factores históricos que operaron como condiciones de posibilidad de la “campaña del terror" desatada durante las elecciones de 1964, que tuvo en su núcleo las distintas formas del anticomunismo presente en Chile. A su juicio, el olvido historiográfico del anticomunismo presenta cierta gravedad, en tanto fue un fenómeno que, por un lado, actúo como un componente de identidad política clave en varios segmentos del espectro político nacional -lo que Casals denomina "polaridad política"-; como por el hecho de que el rechazo al marxismo estaría en la raíz de la violencia estatal perpetrada por la dictadura a partir de 1973 y sus consecuencias. ${ }^{7}$

Del mismo modo, la tematización del anticomunismo chileno permite a Casals entregar una serie de coordenadas que compartimos y que en gran medida sirven de contexto para el análisis específico que hemos planteado de las relaciones polémicas entre catolicismo y marxismo en este artículo: por un lado, el hecho de que el anticomunismo chileno se alimentó de la evidencia de la existencia de un movimiento comunista organizado e influyente en el país, con presencia social y parlamentaria y con efectivas posibilidades de alcanzar el poder. ${ }^{8}$ Del mismo modo, fue la coyuntura de las elecciones de 1964 la que mejor permite cartografiar las distintas vetas del anticomunismo chileno, que pueden diferenciarse en distintas sensibilidades: católica, nacionalista y liberal. ${ }^{9}$ En el específico que aquí nos interesa, Casals considerará a la Iglesia Católica como "el actor no-estatal más empeñado en la lucha contra el comunismo durante toda la centuria, extendiendo su radio de acción desde sus formulaciones institucionales a la práctica política y social de sus adherentes", distinguiendo a su interior la presencia y convivencia de una matriz católicaconservadora y otra social-cristiana, coincidentes en su oposición al comunismo, que operaría como vector de cohesión en lo que el autor que citamos define como "anticomunismo doctrinario". ${ }^{10}$ A partir de ahí, la participación católica en apoyo a la candidatura demócrata cristiana encabezada por Eduardo Frei sería un hecho, convirtiéndose la conceptualización católica del comunismo y sus amenazas en una de las piezas claves de la campaña de 1964.

Sao Paulo, Perspectiva/FAPESP, 2002;María Martha Pacheco, “¡Cristianismo sí, Comunismo no!. Anticomunismo eclesiástico en México”, Estudios de Historia Moderna y Contemporánea de México, 24/2, México, 2002, pp. 143-170; Jorge Rojas F., "Anticomunismo a la chilena: el caso de James Bond en el cómic, 1959-1971”, Revista Izquierdas, 24, 2015, pp. 1-20.

${ }^{7}$ Marcelo Casals A., Anticomunismo, política e ideología en Chile. La Larga Duración de la "Campaña del Terror" de 1964, Tesis para optar al grado de Magíster en Historia, Santiago, PUC, 2012, pp. 10-12. Algo más adelante precisa: "El anticomunismo fue un elemento estructural del desarrollo político chileno del siglo $\mathrm{XX}$, en la medida en que condicionó los términos del debate público e influyó visiblemente en el discurso político de una serie de fuerzas.", pp. 19-20.

${ }^{8}$ Ibid., p. 14.

${ }^{9}$ Ibid., p. 45. "El montaje de campañas anticomunistas no habría podido ser efectiva de no haber existido un campo cultural anticomunista previo que respondiese a las interpelaciones de los mensajes de ese momento", p. 57.

${ }^{10}$ Ibid., pp. 33-34 y 47.

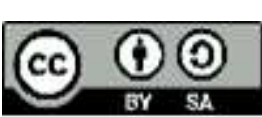


De esa forma, lo que las páginas que siguen buscan es describir e interpretar a partir de un enfoque conceptual la construcción significativa del anticomunismo de matriz católica, poniendo el acento en los debates generados al interior de ésta, así como la topografía de los argumentos esgrimidos y el ritmo de aceleración que la campaña de 1964 supuso para el concepto en cuestión.

\section{I.- Los rostros del comunismo: factores recurrentes del rechazo católico al marxismo.}

Al momento de revisar las facetas más recurrentes que el pensamiento católico elaboró en torno al marxismo -particularizado en el comunismo, sus organizaciones y sus prácticas-, debe anotarse en primer lugar su carácter materialista, que permitió una y otra vez a sus críticos cristianos la elaboración de una identificación paradójica con el liberalismo capitalista, en tanto su persecución del y límite en el homo economicus era a la larga un factor de identidad al mismo tiempo que de incompletitud y debilidad. Así, a juicio de un lector del semanario del Arzobispado de Santiago, La Voz, de inicios de la década de 1960, la consigna de los tiempos era "o cristianismo o materialismo", comprendiendo dentro de este último al capitalismo liberal y al totalitarismo marxista." 11 Pocos meses antes de esta declaración, la revista de la Compañía de Jesús en Chile,Mensaje, publicaba un artículo extraído de la publicación jesuita italiana Stella Mattutina titulada "Cómo superar el comunismo", en el cual se mencionaban varios puntos de interés para el tema que aquí interesa desarrollar. Por un lado, se reconocía el ascenso del marxismo a nivel global, lo que era en alguna medida responsabilidad del fracaso del cristianismo para contenerlo. Este fracaso se sustentaba en las medidas tomadas para combatirlo, que adolecían de tibieza, en tanto no se había comprendido a cabalidad el profundo emparentamiento entre comunismo y capitalismo, hermanados por su materialismo, verdadero núcleo del problema y síntoma de la "crisis espiritual de la humanidad occidental". Así, a juicio del artículo reseñado, el enfrentamiento al comunismo no se daba solo en el plano de las obras de acción social (en el cual se encontraban día a día marxistas y cristianos), sino también en la crítica formal al materialismo y al carácter contra-religioso del comunismo. Para ello se debía desenvolver "una crítica a fondo y objetiva de todas las publicaciones científicas marxistas" y el rechazo y refutación de "cualquier propaganda que quiera mostrar la posibilidad de una distención entre cristianismo y comunismo", en tanto para cumplir con su tarea los cristianos debían "vivir su cristianismo", ofreciendo a sus entornos sociales no un anticomunismo retórico y agresivo, sino que el ejemplo de "un nuevo martirio", derivado de "nuestra resistencia a los poderosos, al dinero, al placer", en tanto "nuestro mayor enemigo no es el marxismo, sino la vida fácil, el afán de enriquecerse, la pagana dulzura de vivir." Solo tras ello, tras este alejamiento testimonial del materialismo por parte de los cristianos se abriría una condición

${ }^{11}$ Eduardo Heilenkoller, "Los católicos “debemos" cambiar actuales estructuras", en La Voz (en adelante LV), 24 de septiembre de 1961, p. 16. 
de posibilidad efectiva de relación con el marxismo, pues implicaría la demostración de un cristianismo al que éstos no conocían, y por ello combatían. ${ }^{12}$

En la misma senda de polémica doctrinal, el número de septiembre de 1961 de Mensaje dedicó su editorial al comentario de la Encíclica Mater et Magistrade Juan XXIII, profundizando tanto en los factores de éxito del comunismo entre los sectores desposeídos de la sociedad, como en sus diferencias irreconciliables con el cristianismo. Así, y tras reafirmar que "el comunismo no es sino el resultado lógico del liberalismo egoísta e inhumano", se argumentaba que la fuerza de rechazo a las injusticias provocadas por el liberalismo era la desesperación, y que ésta era enarbolada como "estandarte de liberación" por los comunistas, quienes a los que nada tenían ofrecían "por lo menos una esperanza terrena", consistente en "bienes puramente terrenales", como "el ángel rebelde ofrecía a Cristo en el monte de la tentación", y sacrificaba al "hombre como tal", en tanto quien se sumara al comunismo debía "someter su amor, su hogar y su patriotismo a la aprobación del "partido"; sobre todo, ha de renunciar a la búsqueda sincera de la verdad. Ha de resignarse a ser simplemente una tuerca en la gigantesca y despersonalizada máquina estatal." Ahí radicaba la diferencia entre cristianos y comunistas, en que los primeros "no pueden vender su libertad por un plato de lentejas", y saben que "el comunismo no es una solución sino un desesperado conato de solución." Consecuentemente con lo anterior, el texto concluía invitando a sus lectores a que "a la bandera roja del comunismo opongamos la cruz pero crucifiquemos primero nuestro egoísmos, nuestras hipocresías, nuestras mentiras, cobardías y ambiciones; seamos, por fin sinceramente cristianos." 13

En un tono muy similar, poco más tarde la misma publicación emprendía la crítica al uso que el marxismo hacía del concepto de socialización, pues en él podían encontrarse funciones esenciales del ser humano, pero que a la luz de su efectuación comunista tornábanse en amenazas para el individuo, en tanto el cambio histórico y el avance de la técnica y la secularización habían multiplicado -a juicio de Juan XXIII en Mater et Magistra- las instancias de socialización como "institucionalización jurídica", que transformaba a éstas de "medio" a "fin", es decir, las volvían planos en los que "los individuos se encuentran encajados y regimentados en importantes actos de su vida, con prescindencia absoluta de su voluntad personal", llegándose con ello al "socialismo integral y al Estado Totalitario, que ningún cristiano puede aceptar por el desconocimiento que importan de la libertad humana esencial". Por tal razón, y aún reconociendo el valor de la socialización en campos como los derechos económico-sociales y la ampliación del campo de referencias y fuentes de información a escala global, el redactor advertía: "pero ¡cuidado! No se trata de dejarnos llevar, así como así, por la corriente de la socialización. Nuestro deber es emplearla al servicio de la libertad de los hombres, de la mayoría de los

12 “Cómo superar el comunismo”, en Mensaje (en adelante RM), 100, julio 1961, pp. 302-303.

13 “Mater et Magistra”, RM, 102, septiembre 1961, pp. 391-394. 
hombres; por tanto, es también luchar contra ella, tratar de desviar su cauce en aquella parte que pase por encima de la libertad humana y la ahogue". ${ }^{14}$

De forma casi inmediatamente paralela, la publicación editada por y orientada hacia los sacerdotes con mayor compromiso con la acción social y política en el mundo popular Pastoral Popular- dedicaba varias páginas a la presentación del marxismo como un adversario central en la sociedad contemporánea. Redactado por el obispo de Temuco Bernardino Piñera, el artículo en cuestión -acompañado de otros referidos al laicismo y al protestantismo- destacaba en primer lugar tanto la larga historia del marxismo en Chile que remontaba a inicios del siglo XX-, como a la suma de factores que lo hacían comprensible, que contemplaban tanto la doctrina de Marx, el apogeo político de la URSS y su política internacional, económica y militar, como el papel de los militantes comunistas y socialistas chilenos, entre los cuales discriminaba entre los socialistas, emparentados con los "trotskistas", de posiciones "más clasistas, más revolucionarias, más violentas" que las de aquellos "comunistas "stalinistas", que militan en el Partido Comunista." Sin embargo, entre ambas organizaciones alcanzaban -a inicios de la década de 1960-, la no despreciable suma de más de 300 mil votos en las últimas elecciones. Por ello, al momento de definir al marxismo, Piñera procedía de forma sistemática, apuntando a sus distintos componentes. En términos teológicos, el marxismo era tanto "un ateísmo negativo, que procura destruir la fe religiosa como un factor regresivo, y en particular destruir física y moralmente a la Iglesia", como un "ateísmo positivo", capaz de mostrar un "mundo sin Dios", un "mundo de progreso científico y técnico, de prosperidad económica y de bienestar material para todos, de justicia y paz." Es decir, el marxismo operaba de forma simultánea al liberalismo capitalista en tanto materialismo secularizante. Junto a ello, el marxismo era presentado como una "cosmovisión" filosóficamente articulada que "tiene una respuesta para todos los problemas", y como un sistema axiológico marcado por su "negación de la moral evangélica, y aún de la moral natural", en tanto se comportaba de forma cínica y fanática, dado que "la moral marxista es una moral política, que se interesa únicamente por los fines, y juzga los medios únicamente desde el punto de vista de su eficacia para alcanzar los fines". Aún así caracterizada, sin embargo, esta moral marxista era

"exigente, y no desprovista de grandeza, una grandeza satánica si se quiere. Exige una ascética dura, y una mística apasionada. Hay en ella girones de moral natural y hasta de moral evangélica, la redención de los pobres, la construcción de un mundo de progreso, de bienestar y de justicia, el establecimiento de la paz universal... Pero arrancadas de su marco natural, deformados, pervertidos, y susceptibles sin embargo de despertar fanatismo entre sus adeptos" 15

En opinión del Obispo, la proyección de esta moral impactaba directamente en los ámbitos social y político, en tanto el marxismo "ha reclutado y formado un ejército de militantes de

\footnotetext{
${ }^{14}$ Luis Burgeois, "La socialización en la Encíclica "Mater et Magistra", en RM, 102, septiembre 1961, pp. 395-399.

15 Bernardino Piñera, "La Iglesia Chilena en medio de las corrientes ideológicas actuales", en Pastoral Popular (en adelante PP), 67, enero-febrero 1962, pp. 5-16.
} 
extracción netamente popular, cuya eficacia revolucionaria y política es indiscutible”, más aún cuando los marxistas eran "revolucionarios en la oposición y dictatoriales en el gobierno", utilizando en la primera de las posiciones una "forma metódica, controlada, sagaz" para promover "el desorden, la subversión, la violencia", de acuerdo a un "plan definido", elaborado con "las adquisiciones de la sicología y la sociología", plan que "revisan periódicamente, con miras a una mayor eficiencia. Los hijos de las tinieblas son más sagaces que los hijos de la luz." A partir de lo anterior, entonces, no quedaba más que definir al militante marxista como "un ateo materialista, un cínico y un fanático, pero a la vez un asceta y un místico, un hombre del pueblo o cercano al pueblo, un revolucionario que será después un dictador-, un militante y un estratega", que ponía todas estas facultades al servicio de "una inmensa esperanza". Este conjunto así resumido de características volvían -aún cuando se observa una suerte de magnificación retórica del comunismo como recurso de inspiración para una lucha por los mismos objetivos así contingentes como filosófico-políticos- al comunismo un enemigo alucinatoriamente formidable, eficiente y peligroso, que conceptuaba -siempre de acuerdo al Obispo de Temuco- a los católicos

"como hombres del pasado, como sobrevivientes de una cultura muerta, como subproductos de un orden social en descomposición, como cómplices y usufructuarios del régimen capitalista, como engañadores del pueblo, como una fuerza regresiva que hay que aniquilar físicamente, y mejor moralmente. O sea, dándonos a elegir, como a la Iglesia rusa, entre el campo de concentración o una sala de museo."16

Luego de tal diagnóstico, lo que los católicos debían hacer era inspirarse en el bíblico David al momento de enfrentarse al filisteo Goliat, que reconoció que ante las armas del guerrero solo contaba con el nombre de Yahvé. Las armas que los cristianos debían entonces preparar eran la revisión de la pastoral, de la educación básica, secundaria, universitaria y filosófica que se implementaba en el país, "los eternos ideales de las bienaventuranzas y de los consejos evangélicos", así como tomando parte en la “transformación económica y social”, factor de participación política que justamente tendía a no considerarse por ser sospechosa de marxismo. Por lo mismo, en el centro de la preocupación obispal se hallaba la necesidad de "acercarnos al pueblo, a tener confianza en él, a establecer en él nuestra base de operaciones, desligándonos poco a poco de los sectores adinerados y poderosos, cuya influencia decrece y que, sin quererlo, nos apartan de las clases populares." 17 De manera igualmente expresiva, por esos mismos días $L a$ Voz advertía sobre la desconfianza de base con la que los cristianos debían observar la actitud política del Partido Comunista de Chile, en tanto "ahora es un partido legal, ordenado,

\footnotetext{
${ }^{16}$ Idem.

${ }^{17}$ Idem. Coherente con lo anterior, el semanario del Arzobispado de Santiago publicaba poco después una crónica en la que saludaba el crecimiento de miembros del PDC entre el profesorado chileno, en tanto eran los docentes los que estaban "en la lucha razonada contra el ateísmo en todas sus formas", en LV, 4 de febrero 1962 , p. 7.
} 
encauzado en moldes jurídicos, respetuoso de la institucionalidad republicana. ¿Hasta cuándo? Hasta cuando deje de convenirle."18

Dicho todo lo anterior, sin embargo, es relevante recordar que al interior de estas mismas publicaciones y debates se articuló una crítica al anticomunismo tradicional, quedando en evidencia la convivencia de matices -siempre críticos- al interior del pensamiento y la opinión católicos en relación al marxismo.Así, por ejemplo, uno de los habituales redactores de La Voz supuso que lo más negativo del comunismo no eran sus proposiciones anticapitalistas, sino que su ateísmo, expresando con ello no solo la necesidad de la "lucha ideológica", sino más bien la poca fortuna que advertía en torno a las tradicionales agrupaciones anticomunistas, vinculadas entre sí solo por principios negativos y no propositivos. Pues bien, al ser contestada la carta por un católico lector que recordaba la integral condena pontificia a la intrínseca perversión comunista, ${ }^{19}$ el redactor del semanario desarrolló sus ideas en una nueva crónica, titulada simplemente "Anti Comunismo", en la cual tanto describía una "espantosa eficacia" en los movimientos comunistas, como su convicción de que "el mundo libre no puede pretender combatir eficazmente a este terrible poder que lo desafía con "anticomunismo". Al decir esto, a lo que el redactor aludía era que, a su juicio, "el único camino del mundo libre es el de una plena consecuencia democrática”, en tanto la democracia podía

"llegar a ser un movimiento unificado, coherente, lógico; capaz de juzgar la realidad con claridad y humanidad, y de descubrir métodos eficaces para construir una cultura, una forma de vida económica y social y un mundo cuyos valores y cuya dirección propios e internos sean: la exaltación de la dignidad inviolable del hombre y su familia; la libertad responsable ante la comunidad en todos los terrenos; la creación personal, original y espontánea en todas las actividades y fundamentalmente en el trabajo, y el compromiso individual, social e internacional de justicia y solidaridad." 20

Pues bien, y siempre de acuerdo al redactor que citamos, lo que el "Anti Comunismo" no poseía era esa "coherencia y consecuencia interna", y que muy por el contrario, se hallaba sujeto más bien a "su psicología pasional y su carencia de principios profundos", que lo encaminaban "a la violencia moral y al despotismo político". Por ello, el compromiso democrático de los católicos debía fortalecerse a partir de lo que el autor denominará "buena voluntad" eficaz y esclarecida, única base posible de una democracia coherente, capaz de levantarse ante la conciencia del hombre moderno no solo como una alternativa para el comunismo ateo, sino que -mucho más allá de la encrucijada actual- como una perspectiva de esperanza y dignidad". 21

De forma sintomática, la reacción a este tipo de postulados dejaba de manifiesto la persistencia de un núcleo de criterios base del anticomunismo "tradicional” católico. Así, al

\footnotetext{
${ }^{18} \mathrm{LV}, 21$ de enero 1962, p. 7.

${ }^{19}$ Edmond Le Maitre, "El comunismo, mortal pestilencia", en LV, 4 de febrero 1962, p. 14.

20 “Anti Comunismo", en LV, 4 de febrero 1962, p. 20.

${ }^{21}$ Idem.
} 
semanario La Voz llegó una misiva escrita por una mujer "católica y chilena", habitante de la localidad de La Ligua, quien decía de sí el no ser "literata y por tanto me falta facilidad de expresión y esa fluidez de palabras que posee, en alto grado, su redactor", aludiendo con tal expresión no solo a la sencillez de su razonamiento, sino mucho más a la incomprensibilidad práctica de las proposiciones del anticomunismo "positivo", en tanto para esta lectora el deber de "combatir al Comunismo en toda forma" no debía estar guiado "por conveniencia política, no por conseguir algún puesto de importancia, no por interés personal", sino que tenía que ser asumido como una forma de "no seguir con la idea absurda de la "mano tendida", tan difundida entre los católicos", reemplazando esta actitud de acercamiento al marxismo por la defensa y conservación de "nuestro Dios, nuestra Patria y nuestro hogar", elementos "que llevamos tan dentro del corazón que no podremos mantener con el Comunismo, ni tampoco defenderlas publicando esporádicamente nuestra "posición", como un vulgar partido político." 22 De ese modo, en apretadas líneas, la mujer que citamos sintetizaba los contenidos del anticomunismo de matriz católica, apuntando hacia el carácter ateo, antipatriota y contrario a la organización familiar que caracterizaría al comunismo, al mismo tiempo que rechazaba cualquier instancia de acercamiento con sus representantes y criticaba con fuerza la inacción o tolerancia que la convivencia política forzaba, añorando gestos de represión efectiva al mismo tiempo que la prescindencia política trascendental supuesta en la Iglesia como institución de mayor alcance que "un vulgar partido político", dejando de ese modo interpretar el componente "supra-político" del enfrentamiento al comunismo, su entidad trascendente antes que contingente, sustantiva al mismo hecho de ser cristiano y no "acomodable" a las necesidades o demandas específicas del contexto histórico.

De forma quizás más matizada pero igualmente directa, al ser preguntado el Arzobispo de Concepción y Rector de la Pontificia Universidad Católica de Chile, Alfredo Silva, sobre los objetivos de las jornadas preparatorias del Concilio Vaticano II -en las que participaba activamente-, indicó que estaba entre las razones de convocatoria al mismo Concilio el que la Iglesia "expresara solemnemente sus principios y su doctrina de verdad frente al error", en referencia a "las doctrinas e instituciones de ideologías anti-cristianas y anti-católicas". 23 Inclusive en opiniones que podrían considerarse menos "anticomunistas" en el sentido tradicional, la fuerza que el combate ideológico tomaba es digna de considerar. Así, por ejemplo, al mismo tiempo que uno de los lectores de La Voz rechazaba el carácter interesado del anticomunismo de muchos católicos, preocupados solo de "la pérdida de sus posesiones y riquezas", subrayaba el hecho de que "para una conciencia cristiana, evidente y necesariamente, lo peor del comunismo es que sea ateo”, y ante ello “¿qué importan las riquezas materiales ante la posibilidad de perder todas nuestras riquezas espirituales?”. Por ello, "la única actitud lógica del cristianismo es promover un poderoso y bien organizado movimiento popular de adhesión a Cristo Rey, como única respuesta valiente y audaz frente al desafío comunista". ${ }^{24}$ De tal forma, y en un juicio apoyado por el redactor del semanario,

\footnotetext{
22 “El Anticomunismo", en LV, 18 de febrero 1962, p. 2.

23 "Único prelado chileno en el Concilio Vaticano II", en LV, 18 de febrero 1962, p. 12.

24 "Gorbea no está solo", en LV, 11 de marzo 1962, p. 2.
} 
la estrategia que el catolicismo militante debía perseguir era la acción política confesional, el enfrentamiento franco y directo en el campo de la política de masas.

A diferencia de la cita anterior la reflexión publicada por el sacerdote Jorge Hourton a mediados de 1962 se centraba en las posibilidades de revisión del anticomunismo católico, posibilidades representadas por el trabajo del Concilio Vaticano II. Así, a juicio de Hourton, era indispensable "purificar y aclarar nuestro anticomunismo", en tanto el marxismo "propicia valores temporales admisibles (la redención del proletariado, el anticolonialismo y anti-imperialismo, la lucha por la paz, etc.)", lo que obligaba al cristiano a "discernir entre lo justo y lo verdadero que puede haber en la causa del comunismo y lo irremediablemente falso y erróneo". Este gesto de reflexión activa que Hourton proponía a los católicos para alejarlos de un "macartismo simplista" suponía un ejercicio a su juicio similar al efectuado en Francia e Italia con las ideas republicanas, en tanto en tales casos los católicos "entraban en estructuras de diálogo con las realidades de la época que no podían ser desconocidas". Por eso, e independiente del destino de la Guerra Fría, "la Iglesia postconciliar deberá contribuir con doctrina e inspiración constructiva a la paz y al desarme de los espíritus" 25 , posicionándose así como una entidad capaz de reconocer elementos positivos de humanización en cada uno de los bandos en pugna, así como de crítica y caminos de superación.

De esa forma, en el plano global del enfrentamiento entre Comunismo y Capitalismo, el cristianismo no tomaba partido de manera doctrinal, sino que -al igual que en la intervención social contingente o la opinión política coyuntural- buscaba operar como una instancia de acuerdo y diálogo entre las partes, instancia la cual suponía la propia cualidad del intercambio, en este caso, con el marxismo. En un sentido muy similar debe ser leída la publicación por parte de la revista Mensaje de las opiniones del jesuita José de Rosa, quien argumentaba que las divergencias explícitas entre el marxismo y el cristianismo no debían derivar en "la formación de Frentes Anticomunistas", en tanto los católicos no podían "colaborar con cualquier anticomunismo; por el contrario, están obligados a rechazar y combatir algunas de sus formas", particularmente "la económica, la nacionalista y la autoritaria, la libertaria basada en una filosofía agnóstica y materialista y muy especialmente la hipócritamente religiosa de quienes pretenden enmascarar bajo la defensa de los principios religiosos y de la Iglesia la defensa de los propios intereses materiales o la inobservancia de los propios deberes de justicia." 26

Pues bien, ante el panorama internacional de multiplicación de instancias de comunicación entre católicos y marxistas, el sacerdote Guillermo Viviani dedicó, a mediados de 1962, un pequeño folleto a presentar de forma crítica la experiencia francesa del "progresismo cristiano", con el fin de advertir de sus riesgos a los fieles chilenos. A su juicio, este movimiento estaba inspirado por tres convicciones fundamentales: "el Capitalismo, causa de todos los males"; "El proletariado es redimido por el marxismo" y "La Iglesia está

\footnotetext{
25 Jorge Hourton, “QQué esperar del Concilio”, en PP, 70-71, julio-agosto/septiembre-octubre 1962, pp. 1415.

26 “Los partidos comunistas y la Iglesia”, en RM, n 111, agosto 1962, pp. 367-370.
} 
enfeudada con el capitalismo". Estos principios eran afrontados por la Iglesia Católica contingente a través de dos estrategias: la "mística de la encarnación" y la "mística de la asunción", consistiendo la primera en "encarnarse en la situación existente para mejorarla, según las posibilidades, procurando elevados salarios, casas de habitación, seguros sociales, etc.". ${ }^{27}$ Para los progresistas cristianos esta primera opción lo que provocaba era "hacer que los obreros reciban valores burgueses", y por ello era considerada "dañosa, porque retarda la revolución", tratando solo "de cristianizar a las oprimidos, en vez de librarlos de la opresión mediante la acción revolucionaria." En oposición a ello, la segunda vía, la "mística de la asunción", suponía para Viviani que "el cristiano asuma los valores del marxismo como propios y colabore directamente en la Revolución, para que llegue pronto la dictadura comunista y el triunfo del proletariado." 28

Evidentemente, la visión de Viviani era contraria al "progresismo cristiano", y aprovechaba su presentación para poner en cuestión una más amplia gama de actitudes cristianas, posibles de ser conceptuadas como anticomunismo positivo. Por ejemplo, como "formas larvadas de progresismo cristiano" consideraba la idea de que "el comunismo no debe ser atacado", en tanto su existencia es producto de las injusticias provocadas por el capitalismo, el cual debe ser reformado a través de "la revolución social con métodos democráticos". Así, "el anticomunismo, la persecución de él por lo que es en sí, es un error; el anticomunismo es una actitud negativa, inútil, que debe rechazarse" porque además "solo contribuye a aumentar su prestigio." Junto a ello, en la misma categoría de "forma larvada" Viviani señalaba la opinión de que "la acción religiosa, la enseñanza del catecismo, la práctica de los sacramentos no tienen actualmente eficacia en el pueblo", estando en la preocupación contingente la superación de la miseria y el subdesarrollo. Ello provocaba que "no faltan sacerdotes que digan que necesitamos más ingenieros y técnicos, que mejoren la situación económica de los países subdesarrollados, que misioneros y sacerdotes, que enseñen el evangelio y la moral." Finalmente, también debían ser ubicados en el cuestionable sector de los progresistas cristianos aquellos que "desvalorizan las doctrinas sociales de la Iglesia, como ineficaces o insuficientes para efectuar un régimen de auténtica justicia social", reemplazando éstas por la defensa de "la propiedad comunitaria, en manos de sindicatos o grandes consorcios industriales y agrícolas, manteniendo, en lo posible, un régimen democrático". De forma global, finalmente, "estos católicos progresistas quieren que la Iglesia se dedique únicamente a su misión espiritual; y le niegan capacidad y derecho para intervenir en lo temporal, en la estructura económica y política de las sociedades modernas." 29

Hecha la presentación, el sacerdote que citamos -siempre con el apoyo de extractos pontificios- iniciará la contra-argumentación de cada uno de los puntos identificados con el progresismo cristiano. A su juicio, en primer lugar, el capitalismo no podía ser entendido

${ }^{27}$ Guillermo Viviani, El progresismo cristiano o los católicos comunistas, Santiago, Ediciones Paulinas, 1962, pp. 7-10.

${ }^{28}$ Ibid., p. 10.

${ }^{29}$ Ibid., pp. 12-13. 
como "intrínsecamente perverso, o el mal en sí. Las injusticias que de él se derivan son abusos de los hombres, de los empresarios inescrupulosos; y pueden ser corregidas". 30 Además, a juicio de Viviani el capitalismo era un sistema centrado en "la práctica", es decir, se mantenía en una suerte de neutralidad moral que al parecer le quitaba gravedad, en comparación con "el socialismo y el comunismo", que "han envenenado al pueblo y le han quitado la fe". Por ello, "el comunismo ha producido el odio de clases, la aversión a la Iglesia y sacude profundamente las estructuras actuales de la sociedad." 31 Junto a ello, "el comunismo va contra el derecho natural al negar a las personas humanas, para entregar al Estado, la propiedad privada de la tierra y de los medios de producción, y reduce al hombre a una terrible esclavitud en manos de un Poder constituido por la dictadura implacable del Partido Comunista." ${ }^{32}$ Así reivindicado el capitalismo al ser expuesto ante el rasero de la amenaza comunista, la pregunta que Viviani buscaba responder era cómo y quién podría lograr la "redención del proletariado", en tanto ninguna de ambas opciones podría afrontar la tarea: el capitalismo "porque subordina todas sus actividades al lucro y es inescrupuloso y no obedece a los principios de la moral cristiana en sus actividades"; el marxismo, por su parte, estaba también incapacitado para dicha labor porque privaba a los trabajadores del derecho básico a la propiedad y los obligaba a vivir en la dictadura.

¿Cuál era la alternativa?: "la Doctrina Social de la Iglesia". ${ }^{33}$ Ésta, a su vez, bien podía ser asimilada a la "mística de la encarnación", tan criticada por los progresistas cristianos, en tanto perseguía "suprimir las injusticias sociales, como se presentan en cada circunstancia y en cada momento y lugar, aunque no siempre logre completamente su objetivo." 34 Por el contrario, la "mística de la asunción" que implicaba plegarse a la revolución conducida por el comunismo -y esto es lo que aquí interesa destacar- suponía para Viviani caer en falta grave, en tanto citaba in extenso el decreto de excomunión emitido por el Tribunal del Santo Oficio en Roma a fines de la década de 1940, del cual colegía que "los que profesan, defienden y propagan el comunismo marxista están excomulgados, es decir, la excomunión recae únicamente sobre los que son verdaderamente comunistas", pero "los cooperadores del comunismo, los que siguen la política llamada de la mano tendida, no incurren en excomunión; pero sí, pecan gravemente", lo cual provocaba que "si con plena conciencia de lo que hacen, persisten en su actitud, se les debe negar la recepción de los sacramentos, como pecadores en materia grave no suficientemente arrepentidos." 35 Para resolver el error, la consideración final del autor convocaba a los "cristianos progresistas o católicos comunistas" a comprender que en la Doctrina Social de la Iglesia -y no en el marxismoestaba "la paz y el bienestar del mundo."36

\footnotetext{
${ }^{30}$ Ibid., p. 15.

${ }^{31}$ Ibid., p. 16.

${ }^{32}$ Ibid., p. 19.

${ }^{33}$ Ibid., pp. 20-21.

${ }^{34}$ Ibid., p. 26.

${ }^{35}$ Ibid., p. 35.

${ }^{36}$ Ibid., p. 38.
} 
En una clave de interpretación que buscaba poner el acento en las situaciones contextuales que explicaban el desarrollo del comunismo en Chile más que dedicar esfuerzos a su cuestionamiento teológico-filosófico, es posible situar al Obispo de Talca Manuel Larraín, quien en 1962 a partir de un comentario a la Carta Pastoral referida al campesinado chileno expresó una serie de juicios sobre el marxismo y su influencia interesantes de reseñar aquí. A partir del reconocimiento de las profundas transformaciones que afectaban a Chile y el continente, Larraín consideraba "que frente a esa realidad social se levanta con ímpetu, organización y estrategia el comunismo ateo", situación sobre la cual matizaba: "el comunismo entre nosotros aun no llega a las grandes masas, pero una estrategia muy inteligente está actuando en los puntos clave de la evolución actual y futura", específicamente "los medios estudiantiles, la Universidad, los Sindicatos obreros, el mundo del arte, el campo (1000 permanentes, "full-time" dedicados al campo)" En ese contexto, el comunismo chileno contaba además con dos factores a su favor: la influencia de la Revolución Cubana - "verdadera revolución social que toma la cultura y todas las estructuras sociales"-, y la efectuada por el "comunismo chino, que por sus características es mucho más próximo a América Latina que el comunismo ruso". Hecha la advertencia, el obispo de Talca se preguntaba "¿nos damos cuenta hasta dónde llega la infiltración marxista? No podemos caer en la ingenuidad de suponer que el comunismo en el poder respetará a la Iglesia. Ni su doctrina ni su táctica, ni su praxis lo permitirán." La clave de salida ante este diagnóstico por parte de Larraín era la implementación de un plan pastoral de emergencia a escala nacional, que entre otras cosas debía volcarse a las zonas descristianizadas o no cristianizadas, en tanto "sobre un pueblo que ignora a Cristo cualquier régimen inhumano puede prosperar"; así como la recomendación a las distintas instancias de la Iglesia a aprender a vivir del dinero aportado por los mismos cristianos, y no de la administración y renta de propiedades agrícolas que si bien en ese momento se hallaban voluntariamente sujetas a un proceso de reforma y traspaso a los campesinos, "prevenimos el evento no difícil que un día cercano la Iglesia pueda ser desposeída de los bienes que hoy la ayudan a vivir." 37

De ese modo, convivían en la opinión de Larraín las "dos almas" que caracterizaban la relación del catolicismo chileno con el marxismo. Por un lado, el reconocimiento de su fortaleza histórica y táctica, así como de la justicia de algunas de sus luchas. Por el otro, el rechazo a su carácter materialista, ateo y totalitario, a la vez que el temor a su posible asunción como forma de gobierno en Chile.

II.- La opinión episcopal y la acción política católica: debates en torno al deber social y político de los cristianos frente al comunismo.

A partir de los criterios de base antes referidos, no debe sorprendernos que para el semanario arzobispal el "rostro anticatólico es el del auténtico comunismo", frase

37 Manuel Larraín, "Notas para una Pastoral de emergencia", en PP, no 70-71, julio/agosto, septiembre/octubre 1962, pp. 26-28. El texto de la Carta PastoralLa Iglesia y el problema del Campesinado Chileno, en http://documentos.iglesia.cl/conf/doc_pdf.php?mod=documentos_sini\&id=968

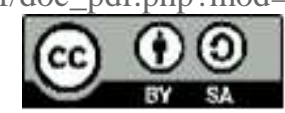


expresada al calor de la polémica en torno a la posibilidad de acercamiento entre cristianos y comunistas, y más todavía, en el contexto de la intensificación de la intervención política y social católica a partir de la Carta Pastoral referida a "El deber social y político en la hora presente", que en septiembre de 1962 definía una línea de activa movilización católica. ${ }^{38}$ La relevancia de este documento en lo referido a la persistencia y caracterización del anticomunismo católico, así como los debates consiguientes, obligan a detenernos con algo de detalle en él. De forma global la Carta Pastoral se centraba en los aspectos propiamente políticos de la participación cristiana en la reforma de las estructuras, y para ello, elegía como primer expediente la crítica al comunismo, pretendiendo los obispos orientar a los católicos en torno a la posición que debían asumir frente a éste, bajo el convencimiento de que el comunismo "no trae el remedio de los males que deseamos extirpar." En primer lugar, esta distancia estaba marcada por los "errores del materialismo marxista", que concebiría a la humanidad como solo materia, y que por ello para acelerar su transformación consideraba legítimo el uso de la violencia contra sus enemigos, dentro de los cuales se incluiría a la religión, en tanto ésta - de acuerdo a los obispos- sería para el marxismo "una institución puramente humana, burguesa y retrograda, opio del pueblo que debe ser perseguida y aniquilada por oponerse a sus planes". Junto a ello, y siempre a partir de referencias a documentos y alocuciones papales, se definía al comunismo como enemigo de la propiedad y la libertad humanas, así como opuesto a la familia y al desarrollo del trabajo individual, debido a su organización colectiva de todos los aspectos de la vida. Todo lo anterior derivaba en una descripción del sistema comunista como insuperablemente antagónico del cristianismo, en tanto

"No existiendo para el comunismo ninguna norma moral superior al hombre, ni ningún poder que esté por encima del poder de la colectividad organizada y representada por el partido, todos los medios para conseguir su fin son lícitos. La destrucción de la idea de Dios, de Patria y de los vínculos más sagrados, como son los que unen a padres e hijos, todo es permitido y bueno para conseguir sus objetivos.

En el régimen comunista los trabajadores no tienen más derecho que los que el Estado quiere concederles; no cabe allí ni el derecho a la información imparcial, ni a la huelga legítima, ni a la libre sindicalización.

La colectividad, representada por el partido que es solo una minoría, y por la organización estatal comunista, es el nuevo dios, el ídolo exigente al que hay que sacrificarlo todo.

El endiosamiento del Estado trae consigo el endiosamiento de los que detentan el poder, a los cuales se les rinde un verdadero y repugnante culto." ${ }^{39}$

Junto a este profundo antagonismo, los redactores de la Carta exponían las que a su juicio eran las razones por las cuales el comunismo avanzaba en el mundo y en Chile: la

\footnotetext{
38 "Vistazo a la Iglesia", en LV, 21 de octubre 1962, p. 3.

${ }^{39}$ Secretariado General del Episcopado de Chile,El deber social y político en la hora presente, Santiago, 1964, pp. 20-21.
} 
capacidad comunista de ocultar sus verdaderos fines e intenciones cuando convivían en régimen democráticos; la decadencia moral del materialismo liberal, su ateísmo propagado en las escuelas y sus abusos en el ámbito económico; "la debilidad e inoperancia de los gobiernos democráticos, la falta de una acción decidida para solucionar los problemas de la hora presente y la prolongación indebida de una situación injusta e intolerable"; la propaganda de escala internacional y su eficiencia "diabólica" "40; la falta de unión y concierto común entre las fuerzas políticas críticas del comunismo, que

\begin{abstract}
"por querer obtener o conservar situaciones de privilegio se prestan al juego de los marxistas y favorecen su ascensión al poder. El comunismo jamás se ha impuesto por la convicción, por el valor de su doctrina; siempre se ha valido de las debilidades de los Estados y partidos llamados democráticos, y ha escalado el poder para constituirse después en el amo implacable de todos los que no piensan como él, comenzando por aquellos mismos que han hecho posible su ascensión. Del triunfo del comunismo en Chile, la Iglesia y todos sus hijos no pueden esperar sino persecución, lágrimas y sangre."
\end{abstract}

Por todo lo anterior, aquellos que colaborasen con los comunistas caían en una conducta inmoral e ingenua, y más allá de ello, no estaban en "comunión" con la Iglesia y serían tenidos por "hijos que se han apartado de la casa paterna". ${ }^{42}$ De esa forma, la Carta Pastoral no dejaba duda ni espacio a la interpretación -aún cuando justamente las divergencias en su interpretación alimentarán múltiples debates que concentrarán nuestra atención- con respecto a la relación entre marxistas y cristianos en el ámbito de la política. Ésta era improcedente, contraria a los valores y a la misma sobrevivencia de la Iglesia como institución. El triunfo de los comunistas supondría, en una palabra, la sovietización de Chile, y colaborar con ese proceso, era traición a las ideas de Dios y Patria que cohesionaban al pueblo chileno, aún por sobre la indigencia en el que el liberalismo lo tenía sumido. A partir de ello, entonces, es importante resaltar el hecho de que la variable doctrinal de la oposición al marxismo no dejó de estar presente en el proceso de renovación eclesial, siendo posible interpretar que la vocación contingente del pensamiento católico y su articulación política no hacía sino intensificarla, en tanto se reconocía como un espacio en el que no era posible un acuerdo o lenguaje común.

Los juicios episcopales antes citados encontraban validación en las representaciones que el conjunto de los católicos expresaban en torno al comunismo, como permite interpretar el análisis de la detallada investigación realizada por el jesuita estadounidense Joseph H. Fichter en torno a las percepciones sobre el cambio social presentes en el mundo católico, la que dejaba en evidencia -tras su publicación en 1962- el persistente y profundo rechazo al comunismo que caracterizaba tanto a los laicos más comprometidos como a la gran mayoría de los sacerdotes. Así, a juicio de más del $80 \%$ de los 328 clérigos residentes en Santiago que respondieron el cuestionario que les fue enviado -más de 400 no lo

\footnotetext{
${ }^{40}$ Ibid., pp. 21-22.

${ }^{41}$ Ibid., p. 22

${ }^{42}$ Ibid., p. 23
} 
contestaron-, los líderes comunistas eran más influyentes que los católicos en los barrios populares, y más del $90 \%$ opinaba lo mismo con respecto al movimiento sindical, siendo el único campo en el que la competencia entre ambos agentes -marxistas y cristianos- era más equilibrada el mundo de las organizaciones universitarias (y no así el espectro más amplio del campo intelectual, en donde se percibía un aumento sostenido de la influencia marxista). ${ }^{43}$ A partir de ahí, entonces, es factible interpretar que esta presencia mayoritaria del comunismo en el campo de las organizaciones sociales sería uno de los factores más evidentes para explicar que, al ser preguntados por "los tres problemas sociales más importantes que enfrenta Chile en estos momentos", el grueso de los encuestados -así laicos como sacerdotes- haya coincidido en nombrar la falta de viviendas, la deficiencia de la educación y el comunismo. ${ }^{44}$

Del mismo modo, un segundo factor que pondría en el centro de la preocupación católica al marxismo era la consensuada percepción de la inminencia del cambio histórico, que para muchos de los encuestados tendría un carácter revolucionario, violento o pacífico, pero revolucionario al fin. ${ }^{45}$ En ese contexto, el carácter pernicioso del comunismo era, en notable medida, remarcado por los católicos encuestados en términos de que éste "despierta el optimismo de la juventud", pero en una clave de "engaño" para cerca de la mitad de los participantes adultos de la investigación. Al momento de acercarse con un poco más de detalle a esta percepción, Fichter anotará un punto de gran relevancia para los problemas abordados hasta aquí por nuestra propia pesquisa: de acuerdo a sus datos, "la gente de edad es más temerosa del comunismo, y ven en él un mayor peligro inmediato que los encuestados jóvenes. La gente joven está más dispuesta a señalar los problemas que ocasiona la interferencia comunista, mientras que las personas mayores señalan el comunismo en sí como un problema." 46 Es decir, los jóvenes laicos y sacerdotes (menores de 25 años en la muestra del jesuita) eran ya capaces en algún grado de diferenciar entre el anticomunismo "negativo" tradicional y uno de nuevo tipo, que se verificaba en la cohabitación efectiva con los comunistas en los ámbitos de la intervención social, cohabitación a partir de la cual se señalaban dificultades y conflictos, pero éstos al parecer no eran esencializados como propios de "los comunistas", sino que comprendidos como factores del contexto en que se desenvolvía la competencia cristiano-marxista. Ya en sus conclusiones, el autor insistirá en esta diferencia, en tanto "no hay duda de que todos los encuestados adoptan un punto de vista desfavorable al Comunismo, y desearían que no fuera una fuerza en la sociedad chilena", pero este rechazo debía interpretarse -en el caso

\footnotetext{
${ }^{43}$ Joseph H. Fichter, SJ, Cambio social en Chile. Un estudio de actitudes, Santiago, Editorial Universidad Católica, 1962, pp. 24, 27, 36- 37 y 80.

${ }^{44}$ Ibid., p. 58. En este sentido es importante agregar que, desagregado por clase social -en categorías en las que los propios encuestados se ubicaban- para los interrogados de clase baja la preocupación por el comunismo ocupaba un quinto lugar en un listado encabezado por la escasez de viviendas y seguido por la cesantía. Por su parte, para la clase media el problema más urgente era la escasez de vivienda y luego la educación insuficiente, ocupando el comunismo el tercer puesto. Para la clase alta, finalmente, el ordenamiento de preocupaciones era el mismo que aquel de la clase media. Ibid., p. 178.

${ }^{45}$ Ibid., p. 96.

${ }^{46}$ Ibid., p. 122.
} 
de aquellos encuestados que Fichter calificaba como de "progresistas"- bajo el principio de que este tipo de católicos "consideran la amenaza comunista como un resultado de los serios problemas sociales que ya existen." Contrariamente, "los tradicionalistas preferirían creer que la gente, particularmente los estudiantes y miembros de las clases bajas, es engañada por la propaganda comunista, antes de aceptar que esa gente está descontenta de las condiciones sociales actuales." 47

Desde esa perspectiva, entonces, será posible comprender mejor las opiniones provocadas por la publicación de la Carta Pastoral. Una de las más sonadas fue aquella que destacaba el explicito anticomunismo del documento. Ante tales dichos, reaccionaron tanto los directamente involucrados -el Partido Comunista- como el Partido Demócrata Cristiano, que en su revista Política y Espíritu tanto subrayaba el carácter crítico del texto de los obispos con respecto al capitalismo liberal (que efectivamente estaba presente en el texto, pero en mucho menor medida que el anticomunismo declarado), como -y es lo que interesa destacar aquí- la necesidad de colaboración con los comunistas, en tanto ello era visto como un factor asociado al hecho de participar "en el movimiento de reivindicaciones sociales, en la lucha contra la miseria", y que podía suponer por ello "formas de convivencia provisorias entre muy distintos sectores ideológicos". La naturaleza del fin superior -el acercamiento al pueblo o la reforma de las estructuras, como se quiera- no era "colaborar con los comunistas" o con cualquier adversario ideológico: "es, simplemente, hacer lo que se debe hacer, ayudar a implantar la justicia en una sociedad injusta." ${ }^{48}$ Es decir, y contra sensu la opinión de la Jerarquía, el redactor de la publicación democratacristiana abría un espacio de convivencia con el marxismo en el ámbito de la acción social, señalizando justamente el rechazo al orden imperante y la urgencia de su reforma como una justificación táctica propia del denominado "anticomunismo positivo." Será, sin embargo, el mismísimo Cardenal Raúl Silva Henríquez quien en una reunión con el Partido Liberal tratara de aclarar los dichos de la Carta en referencia al comunismo, al subrayar que el comunismo era "nefasto para la sociedad humana", debido a que el cristianismo "considera que cambiar los valores y poner al individuo, a la persona humana, al servicio del Estado y no el Estado al servicio del individuo y la persona humana, es nefasto." Por ello, "luchar contra el comunismo significa corregir los males y defectos que hay en la sociedad". 49

Desde otro frente, durante el mes de octubre las organizaciones constitutivas de la Acción Católica Chilena - una docena de asociaciones- suscribieron una declaración en la cual buscaban aclarar las interpretaciones que el documento episcopal había generado en la opinión pública. Tras aclarar el derecho que la Iglesia Católica tenía a comentar los fenómenos socio-económicos, pues "nada de lo humano puede reputarse ajeno al cristianismo", más aún cuando estos fenómenos "atentan contra la dignidad y el destino del hombre", los redactores -encabezados por el presidente nacional de la Acción Católica

\footnotetext{
${ }^{47}$ Ibid., p. 220.

48“"Introducción a la publicación íntegra de El deber social y político en la hora presente", en Política yEspíritu (en adelante PyE), 274, septiembre 1962, pp. 17-19.

49 “Declaraciones del Cardenal Arzobispo Monseñor Raúl Silva Henríquez”, en PyE,274, septiembre 1962, pp. 33-35.
} 
Chilena, Santiago Bruron- dedicaban un aparte sustantiva de su comunicación a aclarar en clave "anticomunista" el documento del obispal. En primer lugar, expresaban el ineludible compromiso que los cristianos debían tener con la transformación de "las estructuras sociales según la doctrina de la Iglesia", apoyando por ello "soluciones eficaces contra la miseria, aunque no sean todo lo perfectas y completas que sería deseable”. Pues bien en lo que aquí interesa, en su opinión "esta labor de transformación debe ser sincera y mirar a una auténtica y real elevación y promoción económica, social, política y espiritual del mundo del trabajo y no orientarse hacia un anticomunismo negativo, tendiente a la derrota y eliminación del adversario, con el fin de conservar mejor y por más tiempo el orden económico y social presente", y que por ello "la condenación del marxismo por parte de la Iglesia Católica no significa, en absoluto, una defensa de las injusticias socioeconómicas en el mundo occidental no comunista", en tanto las formas de vida y subsistencia en estas naciones "distan mucho de ajustarse al ideal de una sociedad humanista y cristiana". En tal sentido, la oposición fundamental era contra el ateísmo del comunismo, en tanto esta crítica estaba dirigida "a conservar para el hombre el concepto y goce completo de su libertad y dignidad, y no a preservar formas e intereses económico sociales superables". Hecha esa aclaración, el texto de Acción Católica se posicionaba ante la lucha política contingente:

"Dos posiciones se observan en la actualidad frente al Comunismo. Una pretende atacarlo exclusivamente con medidas represivas y de fuerza. La otra, comprendiendo que las injusticias sociales son un caldo de cultivo del Marxismo, piensa que en la supresión de estas injusticias está el único medio de contrarrestar la difusión del materialismo marxista.

En el momento presente, el marcado antagonismo entre ambas posiciones no hace más que debilitar la fuerza de su lucha contra el marxismo.

Lo característico de nuestra posición ha de ser el trabajo positivo y urgente para construir un mundo cristiano en todas sus dimensiones, en buscar soluciones cristianas que vayan a la raíz de los problemas; sin olvidar que también es necesaria una firme, pero equilibrada y sensata actitud de vigilancia." 50

De esa forma, la orientación tomada por las máximas autoridades de la Acción Católica chilena -que en este documento se representaba por la Acción Católica de Profesionales, la Asociación de Universitarios Católicos, la Juventud de Estudiantes Católicos, la Juventud de Estudiantes Católicos Femeninos, la Juventud Agraria Católica, el Movimiento Familiar Cristiano, la Asociación de Mujeres de la Acción Católica, el Movimiento Adulto Obrero de la Acción Católica, la Juventud Obrera Católica Femenina y la Juventud Obrera Católica- se desmarcaba del agudo anticomunismo "negativo" que antes hemos reseñado, y se acercaba a posiciones si no de acercamiento colaborativo, al menos sí a la lógica de superación de las condiciones en las que fermentaba el marxismo, y ya no a la eliminación de los marxistas. En el mismo sentido, la lucha doctrinal era central, pero postergable en la "hora actual", aun cuando algunos lectores en particular resolvieran -como salida a este

\footnotetext{
50 “Entre comunistas y anticomunistas. La Acción Católica y la Pastoral”, en LV, 28 de octubre 1962, p. 10.
} 
tipo de polémicas- retirar su suscripción a $\mathrm{La} V o z$, porque el medio "le hace mal a la Iglesia, al país y ayuda al comunismo.",51

Esto último era expresivo sin dudas de la desazón de muchos lectores católicos, quienes reiteraban las cartas de rechazo al anticomunismo "positivo". Así, para una de ellas que habitaba en el exclusivo barrio de Vitacura, la relación con el comunismo se reducía al siguiente axioma: "si no nos defendemos, nos matarán como corderos". 52 De modo similar, y como manifestación de "profunda indignación", otro lector legitimaba el deber y derecho que los católicos tenían de "armarse para defenderse contra el comunismo (no para atacar) que nos está poniendo al borde de la catástrofe", así como "declarar un boicot cerrado a los negocios, industrias, sociedades que favorecen al comunismo", alegando que la oposición a este tipo de medidas era perniciosa. A su juicio, los artículos de prensa que proponían un anticomunismo "positivo" lo único que lograban era "confundir al pueblo sencillo y abrir todas las puertas al futuro comunismo". Por ello, terminaba su carta expresando: “¿Hasta cuándo va a continuar $L a$ Voz en sus estúpidas campañas hipócrita-cristianas?" "53, en abierta alusión a la supuesta inclinación democratacristiana -y por ello abierta al acercamiento con el marxismo- del semanario. De forma muy gráfica, el mismo tipo de rechazo a la supuesta contemporización entre $L a$ Voz y el comunismo se expresó a las puertas de una parroquia, en donde un hombre compró los números del semanario disponibles y acto seguido los rompió frente a todos los asistentes, arrojando sus restos al suelo y proclamando "que era otro el diario que debía venderse en la puerta de la Iglesia.",54

Ante la agudización y violencia en el tono de los descargos anticomunistas, será el director de La Voz, Gastón Cruzat, quien redactará un largo artículo aclaratorio así de la posición del semanario, como de la que a su juicio era la correcta interpretación de la Pastoral episcopal, poniendo en tal sentido el acento inicial en la "realidad angustiosa y anticristiana" que el episcopado denunciaba en su Carta, y que servía como contexto de comprensión así de la "solución comunista" como de la "acción anticomunista" y el necesario "anticomunismo" del catolicismo chileno. Sobre lo primero, es decir, el comportamiento del comunismo, Cruzat no dudaba en sostener que "el comunismo es el peor de los sistemas posibles porque, una vez triunfante, suprime toda especie de libertad y desaparece así toda posibilidad de cambio y de instaurar un orden justo y cristiano, hoy ausente de nuestra sociedad". Por ello, el respeto a las instituciones democráticas y la tolerancia religiosa era solo una táctica previa a la toma del poder, en tanto una vez llegado a éste, "el comunismo mostrará su verdadera cara, destruyendo todo lo que se le oponga".

Dicho todo lo anterior, sin embargo, el abogado expresaba en relación a los militantes comunistas que "son víctimas que hay que salvar del error y no enemigos que hay que destruir", marcando una distancia con el típico anticomunismo negativo. Sin embargo, ello no podía traducirse en un rechazo a todo anticomunismo, en tanto "todo católico, por el

\footnotetext{
51 “¿Ayudamos al comunismo?”, en LV, 4 de noviembre 1962, p. 2.

52 "Anticomunismo y Pastoral", en LV, 11 de noviembre 1962, p. 2.

53 "Más anticomunismo", en LV, 18 de noviembre 1962, p. 2.

54 “iSon católicos?”, en LV, 24 de marzo 1963, p. 2.
}

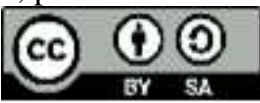


hecho de serlo, es inevitablemente anticomunista", y por ello " $L a$ Voz en este sentido es abierta, total y definitivamente anticomunista y repudia la ideología y la práctica del comunismo". Para que las acciones motivadas por el anticomunismo positivo fueran tales, el redactor recordaba al menos tres condiciones: "que se haga por amor a la verdad y a la justicia", "que busque corregir las causas que provocan el avance comunista" y que "los medios sean lícitos, adecuados y útiles”. En la práctica, a su juicio, el cumplimiento de estas consideraciones derivaría en la implementación del factor positivo que distinguía de la lucha negativa: la realización de "un cristianismo completo, que no se quede solo en lo espiritual, que llegue, por ejemplo... a la justicia social". Por eso "un movimiento anticomunista (que ni siquiera debería llamarse así) necesita orientar su acción principalmente a solucionar la miseria moral y material, a reparar la profunda injusticia social, para lo cual no cabe otro camino que cambiar todo el orden social, económico y administrativo existente". Es decir, la salida a la "solución comunista" no era otra que la "revolución cristiana", o al menos la participación activa de los católicos en la profunda reforma de las formas de organización económico-sociales en Chile, programa que fácilmente puede ser vinculado -a inicios de la década de 1960- mucho más a las propuesta de la Democracia Cristiana que a aquellas representadas por el FRAP, cuyo enfrentamiento electoral en 1964 representaba el telón de fondo de toda la polémica que hasta aquí hemos seguido, y que con razón ha sido analizado como un proceso electoral en el que el miedo jugó un papel fundamental. ${ }^{55}$ Pues bien, el artículo que aquí reseñamos evidenciará una vez más el efecto distorsionante del temor, que solo puede "entorpecer la visión cristiana de la realidad", siendo difícil que "quien se mueve solo por él ayude a construir la Patria que necesitamos", y más bien posible que recurra a acciones ilícitas. Por ello, el camino de la acción efectiva anticomunista era -por ejemplo- "la lucha en el sindicalismo popular", y no el abandono de "las poblaciones y los barrios obreros". Para el director de La Voz, el semanario realizaba un verdadero anticomunismo activo y positivo, consistente en lo fundamental en la denuncia del accionar interesado que los comunistas llevaban a cabo en el ámbito gremial, en las poblaciones "callampas" y en el mundo rural, así como la información constante de la situación en los países comunistas y, hasta ese mismo momento, la clarificación de las orientaciones episcopales. ${ }^{56}$

\footnotetext{
${ }^{55}$ Casals, op. cit., passim.

${ }^{56}$ Gastón Cruzat, "El comunismo, el anticomunismo y La Voz", en LV, 18 de noviembre 1962, pp. 8-9. En la misma senda se inscribieron un par de estudiantes de la Universidad Católica, quienes en carta a $L a V o z$ expresaron su repudio al anticomunismo negativo que alimentaba algunas de las opiniones de lectores del semanario, y valiéndose de citas del sacerdote francés L.J. Lebret, consideraban "una clara diferenciación entre el Comunismo y el comunista. Si bien el Comunismo (en su doctrina y en su práctica) es condenable, a pesar de contener algunos elementos de verdad; el comunista, por el hecho de serlo, NO pierde su calidad de persona ni los derechos que esta calidad lleva implícitos. El cristiano vive para conocer a Dios a través del amor, y nada puede primar sobre esto. No es posible, por lo tanto, odiar a las personas y manifestar este odio a través de una acción negativa (intimidación, boicot económico, agresión armada, etc.) y pretender que se actúa en nombre de "los valores Cristianos de nuestra Civilización"”, Juan Phillips D. y José García G., en LV, 25 de noviembre 1962, p. 2. Un tono familiar a estos argumentos se encuentra en la lectura que de la misma Carta Pastoral hizo la revista Mensaje, que subrayaba la necesidad de unión en torno a las transformaciones urgentes y estructurales que Chile demandaba, y en ese contexto "no es la lucha contra el
}

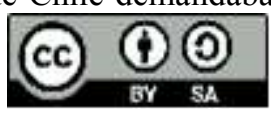




\section{Trascendentalización y eficacia: la crítica doctrinal al marxismo y el campo político católico.}

Siendo coherente con el objetivo de informar sobre la naturaleza del comunismo y con ello debilitar las causas que lo fortalecían, el seminario del Arzobispado de Santiago publicará largos extractos de una conferencia dictada por el sacerdote Miguel Ibáñez Langlois en la Pontificia Universidad Católica con motivo del ciclo de charlas titulado "Marxismo, como teoría y práctica". El texto de Ibáñez L. proponía a fin de cuentas la trascendentalización del marxismo, describiéndolo desde un inicio como "una religión, un dogma y una mística", en un esfuerzo que podemos interpretar como de homologación, asimilándolo al cristianismo con el fin de describirlo en códigos reconocibles para un auditorio católico, y resaltando por ello la versión "secularizada" de la religión que el marxismo representaba a su parecer. De alguna forma, un enemigo trascendentalizado se volvía más comprensible, y al mismo tiempo, adquiría una dimensión fabulosa que a la larga justificaría las medidas que en su contra se trataran de aplicar. La primera clave que hacía del marxismo una especie de religión era la ausencia de prueba y fundamento real de sus convicciones, en tanto para creer en él no debían buscarse evidencias, bastaba solo con la fe, en tanto ésta era el factor que permitía "la falta de pruebas comparada con sus convicciones, la carencia de argumentos comprobativos, la ausencia de fundamento racional para sus principales afirmaciones", demostrado en lo fundamental - a juicio del sacerdote- en "la falta de pruebas y la ambigüedad del materialismo, en la mezcla, filosóficamente inválida, de materialismo y dialéctica", además de la "impotencia de su negación de Dios y la gran simplificación a la que recurre el materialismo histórico".

En el aspecto preciso del ateísmo, Ibáñez destacaba el hecho de que en el fondo de la negación de Dios se encontraba el mismo espíritu "del burgués que denigra, del burgués que invoca a Dios y al espíritu sin creer realmente en ellos", una iniciativa que en el caso preciso del marxismo lo que buscaba era "cambiar a Dios de sitio, sacarlo de su trascendencia y sumirlo en la fuerza oscura de la materia", sacralizando esta última a partir de la concepción dialéctica de la "autodinámica" que suponía a su juicio la proyección de la hipótesis hegeliana del Espíritu al comportamiento de la materia. De esa forma, el orador católico reflexionaba en un tono muy similar a la versión de la secularización que plantea Hans Blumenberg -quizás no casualmente en esos mismos años- en "La legitimidad de la Edad Moderna", en donde argumentaba que el fenómeno de la secularización se había experimentado históricamente en sentidos inversos pero sincrónicos: la temporalización de conceptos de origen sacro para su uso en el ámbito profano; y al mismo tiempo la sacralización de conceptos temporales que así escalaban hacia un plano de trascendentalidadmetahistórica. ${ }^{57}$ Ejemplo de ello, -ahora según Ibáñez- sería el hecho de que el marxismo "al encarnarse en la historia no es una ciencia, sino una moral y una religión”, que como teoría económica y "materialismo integral” no es eficiente, por lo que

comunismo lo que podrá unirnos. La vida no es trinchera, sino conquista y creación", en "Ecos de una Pastoral", RM, 114, noviembre 1962, pp. 525-528.

${ }^{57}$ Hans Blumenberg,La legitimación de la Edad Moderna, Valencia, Pre-Textos, 2009, pp. 13-120.

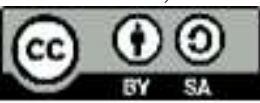


debe llenarse de "idealismo y espiritualidad", y mover su acción a través de una "moral de la libertad revolucionaria y no en el real avance de las fuerzas productivas". Por eso, "la praxis filosófica del marxismo se funda en una energía religiosa del alma, desvinculada de su fuente viva y conducida por los cauces exactamente opuestos."

De esa forma, el sacerdote que citamos volverá sobre la ya conocida paradoja de que el marxismo era una suerte de reverso patológico del liberalismo, en tanto ambas proposiciones se agotaban en un materialismo que, en comparación con el cristianismo, era estéril por su ausencia de espiritualidad y efectiva trascendencia, y por ello, "a todo materialismo solo puede enfrentarse la espiritualidad del cristianismo". Como procedimiento de reemplazo y suplencia de esta falta de trascendentalidad espiritual, de acuerdo a Ibáñez el marxismo elaboró un "mesianismo proletario", cuyo primer síntoma era el hecho de que la mentada "compasión hacia el proletariado pobre y oprimido" que caracterizaba a las versiones anteriores del socialismo, en el caso del marxismo es sustituida por "la adoración del proletariado futuro, fuerte, poderoso, sometedor del mundo entero". Para más abundamiento, "la esperanza del pueblo escogido por Dios, secularizada, se encarna en la clase proletaria, que marcha por la historia hacia la inauguración de un reino de justicia y perfección en los tiempos futuros." Es esta cualidad la que efectivamente movía a los militantes marxistas, la que los excitaba "a la entrega y al sacrificio", la que producía "el entusiasmo propio de los grandes mitos de la historia". En el caso del marxismo, su gran mito habría sido -siempre a juicio del sacerdote que citamos- la Dictadura del Proletariado, en tanto ésta fase de la mecánica marxista de la transformación histórica era "la expresión de un ateísmo esencial e integral, es decir, religioso; esta teoría expresa la exigencia marxista de rehacer el mundo, para lo cual es necesario una dominación total del hombre." Todo lo anterior, en fin, demostraba el carácter religioso del marxismo, y con ello, los factores que definían su incompletitud: como "inversión religiosa", su "acción social desarrolla verdaderos valores"; pero como un "hecho religioso adulterado, que se contradice a sí mismo", no puede "menos que deformar y hacer imposibles los valores que encierra su praxis.",58

De ese modo, y a partir de la lógica de crítica trascendental elegida por IbañezLanglois, lo que se producía era una representación gigantomáquica del marxismo, una conceptualización que proyectaba sobre la acción histórica los principios filosóficos y metafísicos de su constitución, una naturaleza mística y mitológica que, sin embargo, no lograba privarlo de eficiencia histórica, sino por el contrario, la multiplicaba. Pero, y he aquí lo que más interesa destacar aquí, esa misma eficiencia histórica -que como hemos tratado de advertir, se encarnaba en el miedo de algunos y la convicción y entusiasmo ante el cambio histórico en otros- generaba "valores", que podemos entender como significados y conceptos que traspasaban la sola inmanencia de la acción transformadora y se proyectaban "espiritualmente" más allá del tosco materialismo que los utilizaba. Para el mismo orador esa era una de las debilidades centrales del liberalismo, y por ello, el gran diferencial del cristianismo. En la senda de este déficit de trascendencia podemos situar

58 "El marxismo, uno de los grandes mitos de la historia", en LV, 18 de noviembre 1962, p. 11.

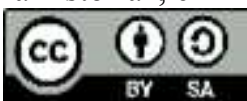


algunas de las hipótesis y proposiciones que con el transcurso de los años irían -a despecho sin duda de Ibáñez- acercando cada vez más a algunos de sus pares sacerdotes con el marxismo. ${ }^{59}$

El desarrollo de contenidos teológicos destinados a poner en cuestión las posibilidades de acercamiento por parte del cristianismo hacia el marxismo puede significarse también en los marcos del número especial que revista Mensaje le dedicó al problema de la revolución en América Latina a fines de 1962. De manera evidente, el ejercicio de conceptualización cristiana en torno a la revolución se planteó en competencia o abierta oposición al uso y práctica que el marxismo hacía de la revolución. Sin embargo, y como el diagnóstico jesuita era el de la inminencia de la revolución en el continente, o más aún, su entidad "en marcha", uno de los puntos a despejar era la actitud que el cristiano debía tomar frente a los movimientos revolucionarios. En ese ítem, el largo artículo que el sacerdote José Aldunate dedicó al deber moral del creyente frente a la revolución es en extremo ilustrativo de los factores que intervenían en la posibilidad de colaboración entre cristianos y marxistas.

A juicio del jesuita, enfrentado el católico a un movimiento revolucionario debía considerar en primer lugar que "su fin sea bueno y que sus medios sean conducentes y legítimos", y a partir de ahí, evaluar la posibilidad de su colaboración con el mismo. La suma de ambos factores permitía al teólogo establecer una suerte de aritmética de la acción política, en tanto aparecía como deseable la colaboración del cristiano con aquellos movimientos dotados de "ideales sustancialmente buenos aunque quizás informes y medios de acción o programas concretos adecuados o al menos posibilidad de adoptarlos"; y por el contrario, su cerrada oposición ante aquellos continentes de "ideales falsos, respecto al hombre y la sociedad y medios eficaces para implantar esos ideales falsos", en clara referencia al comunismo latinoamericano. De manera explícita, Aldunate definía esta oposición en relación a organizaciones e ideas, no a individuos, pues "no es la persona que yerra o falta" y "con ella siempre habrá una posibilidad de diálogo y colaboración”. Por ello, la negación total del reconocimiento con los movimientos revolucionarios era imposible, era inhumano y anticristiano, pues "el cristianismo ha de buscar esos puntos de contacto, desarrollarlos en un diálogo abierto en que esté dispuesto no solo a comunicar sino también a recibir y aprender", siguiendo en ello la lógica de que la colaboración contingente debía estar guiada por la persecución del bien común inmediato, y no mediada por la finalidad última que el movimiento en cuestión se impusiera, aun con el riesgo que esto suponía cuando "la organización del movimiento sea más férrea y totalitaria", citando como ejemplo de esta posible y contextualizada colaboración el caso de "los católicos franceses con el partido

\footnotetext{
${ }^{59}$ Un primer acercamiento a los factores participantes en el acercamiento cristiano-marxista que derivarían en Cristianos por el Socialismo en Marcos Fernández L., "Las vías de la esperanza: compromiso político y debate conceptual en el pensamiento católico chileno. Condiciones de posibilidad para Cristianos por el Socialismo", en C. Rodrigues, G. Zanotto y R. CoppeCaldeira (editores), Manifestacoes do pensamento católico na América do Sul, Rio Grande do Sul, Fonte-FAPERGS, 2015, pp. 179-208.
} 
comunista en el movimiento de liberación contra la ocupación nazi. Es el corolario necesario del mundo actual en que crecen juntos el trigo y la cizaña". ${ }^{6}$

De esa forma -y en una contingencia extrema, sin duda- al definir el límite moral de la colaboración y el diálogo político con el marxismo, éste aparecía como indeseable tanto por el horizonte de concreción de la sociedad comunista, como por los medios dispuestos por sus adeptos para establecerla; pero en la coyuntura latinoamericana la convivencia práctica con los movimientos revolucionarios de inspiración marxista obligaban a la cautela católica, y con ella, a la posibilidad de la colaboración. En la misma línea de cautela y previsión de los riesgos asociados a la acción revolucionaria, el subdirector de Mensaje finalizaba un largo artículo dedicado a la caracterización de la revolución violenta advirtiendo que la única forma de significar de modo auténtico la inminente revolución en América Latina era su cristianización, es decir, el liderazgo que los cristianos debían ejercer en su dirección. Este liderazgo -determinado por multitud de condicionantes gobernados por la relación necesaria entre la bondad de los fines y la licitud de los medios- debía ser consciente que "no está solo en este terreno", sino que constantemente acompañado por el marxismo, el cual "quiere para sí el monopolio de la revolución y asegurar, por lo menos, su iniciativa". Un marxismo al que se representaba, además, como un movimiento que "por táctica, busca colaboradores pasajeros, que luego son arrojados por la borda". ${ }^{61}$

Coherentemente con lo antes expuesto, el último artículo del número de Mensaje que hemos venido citando estaba expresamente referido al "desafío marxista", como factor más relevante de impedimento de una revolución cristiana en América Latina, y por ello, un esfuerzo de tematización que pretendía interpretar al marxismo en la clave precisa de la acción política, y no solo desde proposiciones ideológicas. Con tal eje a la vista, el arquitecto uruguayo y militante democratacristiano Juan Pablo Terra iniciaba su reflexión definiendo al marxismo como "una fuerza lanzada a transformar el continente creando una sociedad más justa, y superando a las otras fuerzas que pretenden construir su futuro". En relación explícita con el cristianismo, el autor señalaba una serie de "aires de familia" entre éste y el marxismo que junto con complejizar la vinculación entre ambos, le reportaba eficacia histórica al comunismo. Así, el "llamado moral a jugarse por la justicia y la liberación de los pobres, unido al sueño de una unidad fraternal en que todos valdrán por su condición de hombres y no por sus posesiones" permitía la consideración por parte de algunos del marxismo como una "herejía cristiana", lo cual permitía a éste "movilizar ciertas fuerzas morales desarrolladas por el cristianismo en la conciencia de nuestros pueblos latinoamericanos". Puestos uno frente al otro, sin embargo, se distinguía a juicio del autor un doble plano de competencia: por un lado, "la transformación técnica del manejo de los bienes y del gobierno de los pueblos", por otro, "una transformación religiosa de sus certezas, de sus valores y sus esperanzas últimas". Esta situación dual,

\footnotetext{
${ }^{60}$ José Aldunate, SJ, "El deber moral ante la situación revolucionaria", en RM, 112, diciembre 1962, pp. 8795.

${ }^{61}$ Gerardo Claps G., SJ, "El cristiano frente a la revolución violenta", en RM, 112, diciembre 1962, pp. 138145.
} 
imposible de divorciar a juicio del uruguayo, daba su auténtica caladura al conflicto, y suponía por ello la elaboración de una serie de hipótesis que representaban las distintas posibilidades de realización revolucionaria en el continente, todas ellas de una u otra forma articuladas a partir del marxismo.

Así, la "revolución propia" suponía la adhesión sin restricciones de los cristianos a un movimiento conducido o motivado por ellos, pero sin la exclusión específica de los marxistas. Tras ella, un proceso revolucionario no conducido por cristianos, pero abierto a su influencia; luego una revolución "ya totalmente o decididamente marxista y en cuya orientación no es posible gravitar más que derrocándola" y por último, aquella en la cual "esta posibilidad ha desaparecido", es decir, consolidada como régimen totalitario en donde "la posibilidad de acción de los cristianos en el plano temporal queda bloqueada", obligándose con ello a una suerte de retorno a "las catacumbas". De esa forma, lo que aquí interesa es revisar los juicios que estas coyunturas hipotéticas refieren a la posibilidad de conflicto o convergencia entre cristianos y marxistas, particularmente en el caso de lo que Terra denominó como "la revolución orientable". En tal situación, la clave a su juicio era la pervivencia del pluralismo, que permitiese la expresión de las distintas sensibilidades y opiniones de las diversas fuerzas que participasen del movimiento revolucionario. Se formulabaasí una suerte de ley que suponía que "en la medida en que el pluralismo interno de las fuerzas revolucionarias subsista, la capacidad de incidencia de un grupo cristiano aumenta. En la medida en que este pluralismo disminuye o desaparece, las fuerzas comunistas por su capacidad de maniobra se hacen virtualmente insuperables."

De esa forma, lo que explícitamente el autor que seguimos expresaba era, en primer lugar, la necesidad de diferenciar a las organizaciones comunistas del resto de las agrupaciones genéricamente definidas como marxistas; y la problemática que surgía al momento de incorporar a un modelo pluralista al Partido Comunista, que en sus palabras, "no tienen títulos para exigirlo, al menos porque su programa y su táctica lo llevan fatalmente a destruir el pluralismo cada vez que alcanza el control de la situación". Sin embargo, la condición del pluralismo debía ser consolidada integrando a los comunistas en él, por dos razones en el fondo tácticas también: por un lado, porque era la mejor formar de contrarrestar su influencia en un marco de libertad de expresión, inhibiendo con ello la eficacia que suponía la actividad clandestina; por otro, porque en caso de exclusión formal, una vez que el PC alcanzase un arrastre popular significativo, encontraría en tal situación la legitimidad para poner en cuestión el conjunto del sistema que lo sometía a exclusión. Así, el pluralismo operaría como "una garantía de que la penetración comunista quedará racionalmente limitada". En síntesis, al dirigirse a los cristianos revolucionarios Terra insistía: "jamás nos dejemos engañar por el ofrecimiento de fusionarnos en una fuerza única, en que la competencia entre comunistas y no comunistas queda librada a un juego sin reglas, sin publicidad, sin garantías". De ese modo, las relaciones entre comunistas y cristianos quedaban marcadas por la vigilancia y sospecha de los segundos sobre los primeros, así como de la defensa de un estado constitucional que permitiese la libre operación de fuerzas políticas que sirvieran de contrapeso a la - su juicio- atávica pretensión hegemónica de los partidos comunistas. En caso de que esta situación de 
convivencia y orientación fuese abolido, el autor democratacristiano era muy explícito: al cristiano le quedara o "trabajar dentro" de la sociedad en tareas vinculadas al bien común, "o lanzarse al derrocamiento", aplicando en ello las reglas clásicas del pensamiento cristiano en torno a la insurrección: el carácter tiránico del régimen, la razonable probabilidad de éxito en la rebelión y que ello derivase en la instalación de un gobierno mejor dispuesto al bien común, el que a su vez compensase los daños y sufrimientos provocados por la insurrección. Como ya antes indicábamos, la última alternativa a una revolución ya caracterizada como totalitaria era el refugio espiritual y las catacumbas. ${ }^{62}$

Pues bien, todo lo anterior derivaba en que las relaciones de colaboración entre cristianos y marxistas se encontraban abiertas en una situación revolucionaria, pero las condiciones de posibilidad de esa colaboración estaban dadas a fin de cuentas por la moderación y contrapeso de la interpretación comunista de la revolución. En caso de predominar ésta, el camino de la insurrección o el repliegue de la acción temporal eran las alternativas. Como último dato, es interesante consignar aquí que a juicio del uruguayo, era justamente Chile donde "la revolución propia es más probable", así como "la revolución marxista respetuosa del pluralismo y orientable". 63

Haciéndose eco de un diagnóstico muy similar al recién citado, el jesuita José Aldunate articulará una contingente reflexión en torno a las posibilidades de asociación y apoyo político entre cristianos y comunistas a inicios de 1963, llevando su discusión más allá de los solos comunistas y aplicando criterios de definición al PC chileno, a los socialistas y los radicales. Con respecto al primero, el juicio del sacerdote era terminante: "el comunismo implica un concepto deformado del hombre y de la sociedad", además de apoyarse "en falsos principios y pretende realizar un orden social que conculca derechos fundamentales y valores trascendentes"; en el caso del Partido Comunista chileno "encarna en su ideología, en sus métodos y sus objetivos, una forma particularmente rígida y sistemática" de los "vicios fundamentales que hemos enumerado", lo que se traducía en que el PC de Chile estuviera "intrínsecamente viciado" y volvía "totalmente ilusoria toda esperanza de que el comunismo chileno en el gobierno pudiera ser diferente de lo que ha manifestado en otras partes." Por ello, un pacto de apoyo de organizaciones de inspiración cristiana a otras de ideología comunista era indeseable; en caso contrario -el apoyo de los comunistas a una coalición encabezada por partidos de inclinación cristiana- era plausible, pues ello implicaría que "no habría concesiones ni complicidades". Pero, y de forma más realista, en caso de volverse necesarias estas concesiones y acuerdos, el asunto se complejizaba, en tanto "es inmoral querer conquistar el apoyo de otros con promesas engañosas que no se piensan cumplir"; del mismo modo, “qué garantía habría de que el comunismo por su parte respetara sus compromisos sin aprovecharse indebidamente de la situación?". Era opinión de Aldunate, en definitiva, que "en el estado actual de nuestra política, con tales combinaciones se correría un serio peligro de contribuir a promover al Partido Comunista más que a comprometerlo, de perturbar la opinión, de desprestigiarse frente a ella, de

${ }_{62}^{6}$ Juan Pablo Terra “El desafío marxista”, en RM, 112, diciembre 1962, pp. 146-152.

${ }^{63}$ Idem. 
orientarla hacia el extremo opuesto. Todos estos resultados comprometerían el fin que se quiere obtener y harían la operación políticamente irracional." Pero, si en última instancia una situación de colaboración con el comunismo se diera, ella tendría que darse teniendo "la seguridad de que no llegarán a dominar el gobierno ni extender su influjo en la ciudadanía comprometiendo el futuro del país." Llevando el ejemplo hasta la propia contingencia, Aldunate cerraba este apartado indicando: "parece que se darían estas condiciones reales entre nosotros, si se pone el poder presidencial en buenas manos."

Con respecto al socialismo, el jesuita se planteaba el problema de la posibilidad de colaboración con éste a partir de dos premisas iniciales: la experiencia europea de acercamiento entre organizaciones democráticas y cristianas con partidos socialistas (la "apertura a sinistra"); y las notorias "divergencias internas" del socialismo criollo, en las que parecía predominar una alianza con el comunismo, fortaleciéndose así el componente marxista doctrinario que hacía que el PS no fuera "por el momento un partido aceptable para el cristiano". En lo central, el riesgo de la complacencia con el socialismo así definido obligaba al cristiano a "distinguir sobre todo entre un sano laicismo y esa intolerancia que quiere relegar al cristianismo a la sacristía", al mismo tiempo que "deberá estar alerta para defender la persona humana contra un estatismo totalitario y una planificación asfixiante." Nuevamente, la ejemplaridad de lo general debía contraponerse al caso contingente de Chile: ¿era posible que los cristianos apoyasen un gobierno conducido por un socialista? Aldunatelo sintetizó así: "en nuestro régimen mucho depende del hombre. Si el hombre es un genuino representante de nuestro socialismo medio, solo se le puede apoyar en la alternativa de un mal mayor. Tendría que quedar excluida según lo expuesto la posibilidad de una dominación o comprometedora infiltración comunista y asegurada por otra la posibilidad práctica de hacer gobierno con el socialismo". ${ }^{64}$

En la misma vía de la reflexión táctica y política, el jesuita Roger Vekemans articuló desde la páginas de Mensaje una descripción de los alcances y fines de la Alianza para el Progreso promovida desde Estados Unidos que, en su núcleo central, debía ser entendida como una vía de contención del comunismo en América Latina. Sí, puestoque a su juicio el continente se veía atenazado por una doble presión histórico-social: por un lado, la prevalencia de la miseria, agudizada por "los efectos del despliegue espectacular no solo del bienestar de los países desarrollados, cuya imagen se proyecta por los medios modernos de comunicación aun hasta la más modesta choza, sino también por el lujo ostentoso de las clases privilegiadas nacionales"; por otro, la existencia de "una ideología, accesible hasta al más analfabeto, que haya asumido la tarea de exacerbar la irritación provocada por las extremas diferencias sociales, conservando envenenadas las heridas y amargo el resentimiento." Si bien no es este el lugar para discutir la eficiencia del programa de transformaciones inspirado por Washington en la primera parte de los años 60, es importante recordar el papel clave que en su difusión jugó particularmente Vekemans, así como su coincidencia con lo que sería el programa y luego una parte sustantiva del

${ }^{64}$ José Aldunate, SJ, “Los pactos electorales, un problema de conciencia”, en RM, 116, enero-febrero 1963 , pp. 33-41.

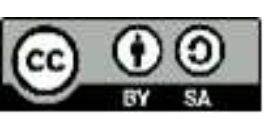


gobierno de la Democracia Cristiana en Chile. En tal sentido, entonces, la definición que ahora interesa destacar es que para el jesuita, la ausencia más notable del diseño norteamericano era el pueblo latinoamericano, los marginales; y el riesgo que ello significaba estaba signado por el hecho de que eran los comunistas quienes sí tenían acceso a las masas populares, entre las cuales actuaban los "agitadores marxistas", dedicados a la "implacable oposición" frente a las reformas promovidas. Para Vekemans, el filón táctico de la incorporación - de la "promoción"- de los sectores populares al impulso de las transformaciones estructurales era anticomunista, en tanto el comunismo "que no acepta consideraciones legales en su camino, que no se cuida en absoluto de la soberanía nacional y muy poco de las estructuras partidistas establecidas, ha concentrado sus actividades en las organizaciones populares", provocando con ello que "mientras la Alianza espera alcanzar a las masas latinoamericanas a través de los gobiernos y partidos establecidos, los comunistas están lanzados a la conquista del poder a través de las masas." El resultado de ello era en lo inmediato trágico según el jesuita, dado que

"el agitador comunista es un profesional pagado y bien equipado con todos los medios de propaganda que pueda necesitar, al paso que los que se alzan para sostener, consentido realmente popular, los valores e ideales concurrentes a la Alianza son hombres generalmente aislados, sin ayuda, a menudo perseguidos por los intereses económicos que detentan el poder político o policial.

La paradoja es obvia: en el alto nivel, recursos sin hombres, o al menos sin bases populares, y en las bases, hombres sin recursos. Para decirlo con sencillez: por la acertada combinación de ambos -hombres y recursos- el Comunismo está teniendo mayor éxito con menos hombres y menos recursos. Tal vez, a largo plazo, la estrategia de la Alianza pueda resultar mejor. Pero ¿de qué nos sirve disponer de una estrategia concebida para ganar a largo plazo, cuando solo disponemos de un plazo corto?"65

De esa forma, y a contrapelo del ánimo de acercamiento entre cristianos y marxistas que podía interpretarse a partir de la encíclica Pacem in Terris publicada por Juan XXIII en abril de 1963, entre los segmentos más visibles del pensamiento católico chileno se fortalecían los argumentos de oposición cerrada frente al comunismo. Así, desde las páginas de $L a$ Voz se daba cuenta del debate en torno a los alcances del potencial acercamiento, en tanto, junto con el rechazo a la revolución violenta característica del pensamiento católico que hasta aquí hemos reseñado, el redactor del semanario daba cuenta de que al alternativa "evolucionista" sostenida en ocasiones por el comunismo era igualmente peligrosa, en tanto la apelación a la paz y la colaboración podían ser factores "maquiavélicos" del accionar comunista, tácticas que ocultaban sus verdaderas intenciones:

\footnotetext{
${ }^{65}$ Roger Vekemans, SJ, “¿Quiénes son los “Aliados para el Progreso?”, en RM, 117, marzo-abril 1963, pp. 90-96. La relevancia del jesuita belga en el periodo -así en la organización de los centros de pensamiento e investigación de inspiración católica como en la articulación de una teoría de la marginalidad que daría sustento a las políticas sociales del gobierno de Frei Montalva- fue variada y polémica, por lo que esperamos dar cuenta de ella a cabalidad en publicaciones ulteriores.
}

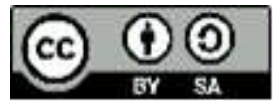


"para el cristiano, la principal repugnancia no es contra el "revolucionarismo" violento comunista, sino contra el "evolucionismo" táctico y pacífico comunista. Porque percibe en este último lo peor de todo; peor que la violencia y crueldad del totalitarismo: percibe el "maquiavelismo", la mentira deliberada y sistemática del que se declara "amigo" para ser un mejor, más eficiente y más poderoso enemigo en el momento oportuno. Muchos cristianos identifican la idea del comunismo con la idea de la traición, no tanto porque crean "traidores" a los comunistas, sino porque les horroriza que la "convivencia pacífica" pueda ser, para ellos, "un instrumento táctico o estratégico". El cristiano tiene una debilidad literalmente "divina" por la convivencia pacífica, que es una preciosa e inestimable manifestación del amor, y, para él, el que la "usa" como instrumento de ventaja personal es un "hipócrita", un habitante congelado del noveno foso del infierno de la Divina Comedia: "apenas acomete el alma una traición, arrebata su cuerpo un demonio"; pero el que la transforma en un sistema y en una táctica se hace compañero del demonio." 66

Como era previsible, la cercanía de las elecciones presidenciales de 1964 agudizó el posicionamiento político explícito de los católicos, y en ese contexto la relevancia de la oposición a la colaboración con la izquierda fue un factor recurrente. Más aun a partir de la articulación de "Izquierda Cristiana", un movimiento de católicos comprometidos con la candidatura de Salvador Allende. ${ }^{67}$ Las reacciones a su visibilización pública fueron expresivas de la continuidad de los contenidos que hasta aquí hemos reseñado: a juicio del lector de $\mathrm{La} \mathrm{Voz}$ J. Govenec -y en respuesta a la definición de "Izquierda Cristiana" de que ellos "al estar junto al pueblo, interpretarían la doctrina cristiana"- "el cristianismo como doctrina filosófica y social no puede someterse a divisiones de tipo político en derecha, centro e izquierda", dado que "el cristianismo es uno solo e indivisible. Se es cristiano o no se es", y en esa lid, "el marxismo ateo, materialista y antirreligioso no puede ser el ideal de un cristiano", en lo fundamental debido a que la doctrina de Cristo tenía "como piedra fundamental el respeto a la dignidad del ser humano", mientras que "el marxismo lucha por alcanzar su objetivo sin importarle los métodos; se dice que el fin justifica los medios y eso ha llegado a ser un verdadero dogma." El listado de oposiciones continuaba, en tanto

"los partidos marxistas afirman que no existe otra cosa que la materia. Califican a la religión de invención burguesa y retrograda que debe ser aniquilada por oponerse a sus planes. Suprimen toda dignidad humana y freno moral, atribuyendo a la colectividad los derechos naturales propios de la persona humana. La propiedad privada debe ser eliminada por ser la causa principal de la esclavitud económica. Conceden al Estado el arbitrario poder

\footnotetext{
${ }^{66}$ José Gorbea, “Revolución y evolución”, en LV, 19 de mayo 1963, p. 16.

${ }^{67}$ Esta agrupación habría desaparecido tras las elecciones, perdiéndose su pista en la documentación revisado hasta ahora, por lo que queda pendiente la definición si existió continuidad entre esta organización y aquella articulada a partir de la escisión del Partido Demócrata Cristiano en 1971.
}

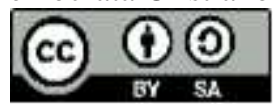


de emplear todos los medios por inhumanos que ellos sean para conseguir el objetivo." 68

Por todo ello, a juicio del lector "no hay duda de que quien apoye o ayude a la implantación de un régimen marxista no puede ser cristiano ni calificarse de tal." ${ }^{.69}$ Sin ser tan tajante, por las mismas fechas el semanario del Arzobispado remarcaba las palabras del Cardenal Silva Henríquez referidas a la posición frente al comunismo que había definido la Pastoral de 1962, recordando que "con el comunismo no podemos ir, imposible", y que no debía concebirse que por algún tipo de factor "estamos necesariamente expuestos y entregados al comunismo, que el comunismo es una solución que la Providencia nos ha ofrecido para extirpar nuestros males". Muy por el contrario, la búsqueda y concreción de la "solución cristiana" era el camino para que "nuestro pobre pueblo, desprovisto de tantas cosas" no fuese "desprovisto de su religión y de la poca libertad que le queda", en clara alusión a las a su juicio potenciales consecuencias de un triunfo comunista. ${ }^{70}$ En términos muy similares se expresaba la redacción de $L a V o z$ ante la insistente pregunta de si era factible la existencia de "católicos allendistas", al expresar que "no creemos que haya compatibilidad entre los principios cristianos y marxistas", en tanto aparecía como "imposible conciliar una filosofía eminentemente espiritualista con una rotundamente materialista". Además, "sería hacer muy poco honor a la honestidad intelectual y a la sinceridad del senador Allende el suponer que, llegado al poder, haría un gobierno contrario a sus propias convicciones o sustancialmente apartado de ellas." Por ello, en síntesis, “opinamos, pues, que los católicos allendistas, en el mejor de los casos, están errados o respecto a su catolicismo o respecto a la doctrina del movimiento que apoyan.,"71

Consciente del ascenso de lo que no tardaría en denominarse como "Campaña del Terror", la publicación de los jesuitas chilenos trató de poner algo de serenidad en el ambiente político nacional y, especialmente, entre los católicos, a quienes convocaría a no caer en el juego del "sálvese quien pueda" y a dejar de imaginar "un futuro de tropelías, de rencores desatados, de paredones, de violencias y saqueos, de libertad aherrojada, de masacres y calabozos" ante la posible victoria del FRAP en las elecciones de ese año. ${ }^{72}$ Con particular dureza se criticaba a aquellos que "reservan pasajes de avión para abandonar el barco tan pronto el temporal arrecie", al mismo tiempo que sacaban dólares de forma fraudulenta del país.

A juicio de Mensaje, el camino ante la teórica victoria de Salvador Allende no era la sumisión ni el pánico, sino el tratar de evitarla, no huyendo a la desesperada, sino que "luchar hasta el fin", uniendo "nuestras mentes, nuestras voluntades y nuestros brazos". Los

68 “¿Derecha, centro, izquierda?”, en LV, 15 de marzo 1964, p. 2.

${ }^{69}$ Idem.

70 "La clase del Cardenal en Valparaíso", en LV, 19 de abril 1964, pp. 12-13.

71 "Católicos o allendistas", en LV, 26 de abril 1964, p. 2.

72 El FRAP fue el Frente de Acción Popular, coalición de partidos de izquierda entre 1956 y 1969 , cuyo candidato en las correspondientes elecciones presidenciales fue Salvador Allende G. La alianza que lo sucedió fue la Unidad Popular, con la que el mismo triunfaría en las elecciones de 1970. 
que huían eran tomados por desertores, en persistente analogía con el proceso de Independencia a inicios del siglo XIX, en donde los verdaderos héroes combatieron hasta el final, sin desanimo. De forma muy explícita, la editorial de Mensaje que citamos dejaba en claro dos cosas: que el triunfo de la candidatura de izquierdas era representada como un peligro y una derrota para la línea de la revista; y que ante esa inminencia, era indispensable recurrir a principios cristianos, en lo fundamental, al de la esperanza, acompañada de la prudencia. Sí, puesto que el resistirse a huir y proclamar la urgencia de la lucha "de ninguna manera significa un optimismo ingenuo", a la vez que "ignorar o minimizar al adversario no es vencerlo sino fortificarlo." De esa forma, la prudencia era entendida como virtud, y "la auténtica virtud es fuerza". Para los redactores "la prudencia cristiana es hermana de la esperanza y, por lo mismo, es fortaleza y magnanimidad.,"73

Al parecer, el tono de enfrentamiento que el artículo antes citado tenía provocó, al interior del mismo comité editorial de Mensaje una reacción, en términos de que las páginas introductorias del siguiente número fueron dedicadas a tratar de responder a algunas de las preguntas que -en sus palabras- sus lectores habían formulado. “¿Hasta cuándo la Iglesia vivirá cultivando el miedo? ¿Por qué mirar con predeterminada desconfianza todo lo que sea cambio social, político o económico? ¿No es el marxismo una reacción natural contra hechos injustos?". De forma puntual, los redactores de Mensaje se enfrentaban a las preguntas de “¿Por qué la Iglesia tiene que sentirse anticipadamente atacada? ¿No se identifica con la injusticia que el marxismo denuncia? ¿No transforma en adversario a un movimiento que podría haber sido su aliado?" Las respuestas dadas pueden ser interpretadas como puntos de retorno a posiciones que se alejaban de la idea del diálogo, para avanzar hacia definiciones tajantes que sintetizaban de forma hasta sorprendente los tópicos que hasta aquí hemos tratado de resaltar, pero muy pocas veces usando materiales provenientes de la revista jesuita.

Así, se reconocía que "debemos aceptar muchas de las críticas que el marxismo hace al orden actual, y el "escándalo" que denuncian los marxistas ha de ser realmente "sentido" por nosotros e incitarnos a luchar eficazmente contra la injusticia." Sin embargo, el marxismo no era la única fuente de denuncia de las injusticias, y a la larga éste era "esencialmente un ataque a la Iglesia", dado su carácter "intrínsecamente anti-católico, anti-religioso, anti-teísta." A su juicio, "no es la Iglesia quien primero atacó al marxismo, sino el marxismo a la Iglesia", y la reacción de ésta estaría basada en que "ve en él una filosofía errónea, un sistema injusto que no solo amenaza al cristianismo sino al hombre en general." En el plano del alineamiento político específico, y ante las críticas de la defensa interesada de un orden injusto, el redactor era muy claro: “¿Por qué reemplazar un orden injusto por otro no menos injusto? ¿No parece mucho más lógico buscar una solución justa que suprima efectivamente las injusticias?" Estrictamente, "el orden actual es injusto pero nos deja por lo menos la libertad de criticarlo", en tanto que "el marxismo una vez instalado en el poder no admite oposición ni critica". En la misma dinámica de argumentación, para reafirmar el rechazo al corpus filosófico del marxismo -definido como dialéctico y

73 “Miedo y Esperanza”, en RM, 128, mayo 1964, pp. 139-142. 
materialista- se argumentaba: "estamos de acuerdo en que debemos luchar sinceramente contra todo materialismo y dejar de quemar incienso ante el dios dinero, pero de aquí a aceptar la doctrina política y económica del marxismo hay un abismo. Y conste que no lo rechazamos por miedo sino simplemente porque nos parece falsa, porque de hecho despersonaliza al hombre y lo transforma en un mero instrumento del "partido"”. Así, la depuración de la filosofía del marxismo de su comportamiento político era imposible, al igual que hubiera sido hacerlo con el nazismo, cuando "Auschwitz o Dachau eran una concreta y macabra síntesis de filosofía y política racista." Así, el materialismo y la preeminencia del Partido por sobre el sujeto hacían del marxismo una fuerza deshumanizante, y ello se hacía evidente por la máxima cristiana de que "no es la sociedad la que humaniza o personaliza al hombre sino el hombre a la sociedad". Más aun, en caso de triunfo comunista parecía inevitable la implementación de la "máquina totalitaria", aquella "prácticamente imposible" de derrotar desde adentro, y que dotada del "inmenso poder de la técnica moderna" se volvía "super-humana o, mejor dicho, in-humana".

Al finalizar el texto, los redactores de Mensaje dejaban muy en claro los márgenes de maniobra que quedarían a los auténticos cristianos -aquellos que no se escondían, aquellos que estaban dispuestos a seguir el ejemplo de los mártires- en caso del triunfo de la candidatura del FRAP:

"Supuesto que un régimen marxista se instale en Chile ¿cuál ha de ser la actitud del cristiano? ¿Esconderse? ¿Huir? ¿Oponerse al régimen pase lo que pase? Una cosa es contribuir a que el marxismo logre el poder y otra cosa muy diversa es tener que habérselas con un régimen ya instalado. De ninguna manera nos parece lícito que un católico contribuya a que el marxismo se instale en nuestra patria. Pero en el caso de que triunfe el marxismo y llegue a ser gobierno, no puede evidentemente la actitud del católico ser ante todo un timorato esconderse o un mero afán de escapar; lo que no excluye que puedan haber circunstancias que legitimen y aconsejen huir. Tampoco nos parece legítima la actitud de oponerse a todo lo que el gobierno haga, sea malo o bueno. El católico podrá y deberá colaborar en lo que sea bueno y oponerse con valentía a todo lo que sea incompatible con su fe cristiana. Aunque el "diálogo" sea difícil y quizás imposible, debe esforzarse porque se mantenga. En todo caso no debe ser él quien haga el diálogo imposible. Y en este caso, sí, tendrá el católico que abandonarse a la Providencia divina; luchar por el bien común, esforzarse porque el marxismo sea menos marxismo; rezar, esperar, y si es necesario estar dispuesto a morir antes que traicionar su fe; y Dios hará el resto." 74

74 "El cristiano frente al marxismo", en RM, 129, junio 1964, pp. 205-211. 
Como la cita referencia anterior ejemplifica, la agudización de las diferencias y la toma de distancia con el marxismo no hicieron sino acrecentarse conforme se aproximaban las elecciones de septiembre de 1964, dando cuenta la prensa arzobispal de una serie de ofensas en contra de la Iglesia de parte de medios de prensa asociados al FRAP. ${ }^{75}$ Junto con ello, se retomó un tipo de argumentación propia del "anticomunismo negativo" a la usanza en medios de opinión católica más tradicionales que La Voz. Así, a pocos meses del acto eleccionario se sumaban notas y editoriales destinadas a definir con toda claridad las fronteras entre cristianismo y marxismo, límites que en lo práctico se manifestaban en el hecho de que -y se parafraseaba al obispo francés Emile Guerry- "los comunistas reprochan a la Iglesia el no doblegarse a las propias concepciones comunistas", por lo que, mientras eso no sucediera, "el comunismo seguirá tratando de tener sus católicos "propios", los cuales se rebelan contra las directivas de la Jerarquía." Así, el marxismo era comprendido -a la luz de la articulación de movimientos de cristianos que se asociaban explícitamente con la izquierda- como una fuerza faccionalista al interior de la Iglesia, factor que con el paso de los años adquiriría una dimensión de gran profundidad. ${ }^{76}$ Por ahora, en los primeros años de la década de 1960, operaba solo como una advertencia.

Junto a ello, se volvía a recordar el tópico de que "el marxismo quiere constituirse en una verdadera religión", limitando a su vez al catolicismo a operar solo "al interior de los templos", no en la vida política efectiva. Muy por el contrario, el llamado de la prensa arzobispal era a que los católicos reconociesen que "su religión implica una forma integral de vida", siendo ello manifiesto tanto en "el derecho de adorar a Dios en el templo", como "de llevar a la práctica la doctrina social cristiana". Más allá de ello, el compromiso político -ahora marcado por el rechazo al comunismo- se establecía a partir de la convicción de que "el cristianismo mira hacia el cielo, pero tiene los pies en la tierra", lo que significaba "el derecho de enseñar y difundir su doctrina, de tener escuelas y universidades, de tener agrupaciones y participar plenamente en la vida ciudadana." Por eso, la Iglesia no "interviene en política, señalando candidatos o partidos. Pero si tiene el derecho y el deber de orientar a los católicos." 77

Como estandarte de esta máxima, el semanario arzobispal dedicará desde ese momento en adelante parte importante de sus páginas a la síntesis y actualización constante del enfrentamiento entre comunistas y católicos, asumiendo para ello una retórica belicista y clausurada a cualquier posibilidad de acercamiento. Así, bajo el significativo título de "Guerra de guerrillas: la estrategia religiosa del marxismo", a mediados de 1964 se publicaba una larga lista de agravios y declaraciones provenientes del FRAP y que de

\footnotetext{
75 "No son coincidencias", en LV, 21 de junio 1964, p. 3.

${ }^{76}$ Fernández, op. cit., pp. 204-205.

77 “El comunismo y los católicos", en LV, 21 de junio 1964, p. 7 El recurso a la ironía se volverá rutinario en esta etapa del debate. Un ejemplo de está representado por el "Credo comunista" publicado por La Voz: "Creo en la materia, eterna, infinita, inacabable, autodinámica, omnipresente; creo en la dialéctica y en sus leyes. Creo en la meta de su evolución: el paraíso en la Tierra. Creo en la conciencia del proletariado; creo en Marx y Lenin, a través de quienes nos ha sido revelada esta conciencia. Creo en la infalibilidad del Comité Central del Partido." "El marxismo: una religión al revés", en LV, 21 de junio 1964, pp. 8-9.
} 
acuerdo a los redactores buscaban un solo objetivo central: la división entre Jerarquía y pueblo católico, presentando a la primera como "reaccionaria frente a fieles de avanzada". Para ello se acumulaban los sistemáticos informes de Orlando Millas ante el Comité Central y los versos satíricos de Neruda, las querellas filosóficas de VolodiaTeitelboim con las denuncias periodísticas de parroquias rurales donde se explotaba y engañaba a los creyentes, la situación de privilegio de las instituciones educativas privadas y el cohecho electoral representado por Cáritas. De forma específica, la crítica al intervencionismo político tanto del Cardenal Raúl Silva Henríquez, como de quien era tenido como el "estratego" de la campaña de Frei Montalva: el jesuita Roger Vekemans, señalado como quien habría redactado la Pastoral de 1962, habría elegido al PDC para hacer efectivos sus presupuestos y habría designado a Frei como candidato. Así, Vistazo, El Siglo, Principios y Última Hora eran las herramientas utilizadas por el FRAP para distanciar a la opinión popular cristiana de la Iglesia Católica, proceso que -siempre en la lógica de la nota que citamos- encontraba su culminación en la articulación del Movimiento Católico Allendista, que graficaba el horizonte marxista de "dividir para reinar." En síntesis, para La Voz esta suma de eventos representaba la operación de la "táctica de las guerrillas, trasplantada ahora al plano de las ideas: rehuir el encuentro frente a frente; hacer una intrusión o lanzar un ataque y retirarse; eliminar al enemigo poco a poco, debilitándolo.,"78

Todo ello reflejaba de forma muy explícita el tono de crispación que caracterizó a la parte final de la campaña electoral del 1964, su virulencia y el uso de temores y fantasmas, de rumores y ambigüedades. Incluso el mismo semanario arzobispal lo percibió como un fenómeno riesgoso como el que más, en tanto en vísperas de la elección se habían introducido "una áspera tensión introducida por los rumores de violencia que recorren nuestro ambiente", rumores que parecían facilitar que "la mentalidad nacional" se preparase para "aceptar la violencia, como un elemento no deseable, aunque sí inevitable. Cada cual cree que vendrá del otro lado, que la provocarán los otros, más no duda de que vendrá." Ante ello, La Voz pedía "que la ciudadanía adopte una actitud a la vez resuelta y serena."79 Y era esa la actitud que saludaba una vez realizada la elección y conocidos sus resultados, en tanto "el pueblo de Chile demostró, una vez más, que sabe ejercer sus derechos ciudadanos con limpia entereza, con sinceridad, con respeto por las opiniones y actitudes ajenas y, sobre todo, con una especie de instintivo sentido jurídico. ${ }^{80}$ Es decir, una por una, las cualidades que la articulación del anti-comunismo católico negaba en el marxismo y el comportamiento de sus representantes.

\footnotetext{
78 Javier Rojas U., "Guerra de guerrillas: la estrategia religiosa del marxismo", en LV, 21 de junio 1964, pp. 10-11. La colección de las opiniones del diputado comunista Orlando Millas en torno a la participación del catolicismo en el campo político chileno del periodo se encuentra en Los comunistas, los católicos y la libertad, Colección Realidad Americana, Editorial Austral, Santiago, 1964. Agradezco la recomendación de este texto al historiador Alfredo Riquelme $\mathrm{S}$.

79 "La mentalidad del mientras tanto", en LV, 30 de agosto 1964, p. 3

80 "Chile dijo su palabra", en LV, p. 3
} 


\section{Conclusiones}

Para terminar, es factible a partir de las evidencias presentadas y el marco de interpretación propuesto proponer una serie de conclusiones que, de manera sintética, den cuenta de las relaciones de antagonismo articuladas por el pensamiento católico en relación al marxismo a inicios de la década de 1960. Así, en primer lugar se destaca con claridad el papel de cohesión al interior del pensamiento católico que la oposición al comunismo jugó, en tanto los matices y diferencias que se insinuaron entre algunos de sus actores con respecto al anti-comunismo y sus alcances, fueron disueltos ante la coyuntura de la factibilidad de un triunfo del FRAP en las elecciones de 1964, siendo en esto el caso de la revista Mensaje un indicador explícito.

Del mismo modo, la construcción, ampliación y profundización de las argumentaciones anticomunistas que aquí hemos revisado son expresivas de la vocación política del pensamiento católico en el periodo, en términos de privilegiar la articulación intelectual, filosófica y teológica de la reflexión política, asumiendo con ello una visibilización en la arena pública difícil de hacer coincidir con el presupuesto -siempre útil de revisar- de la condición secularizada de la esfera pública en el Chile del siglo XX. ${ }^{81}$ De esa forma, a través del debate contra el comunismo los intelectuales católicos -que actuaban en tanto tales, es decir, haciendo un uso público de sus competencias disciplinares- ${ }^{82}$ se incorporaron activamente al ruedo político contingente, volcándose a una lucha ideológica de hondo calado y prolongada extensión.

El carácter efectivo de este combate ideológicamente articulado tuvo al menos dos planos que resultan interesantes de resaltar: por un lado, la asociación que se estableció entre las formulaciones críticas hacia el marxismo producidas por el pensamiento católico y su inversa simpatía con respecto a las proposiciones encarnadas por la candidatura de la Democracia Cristiana, factor reconocido por el común de los agentes políticos contemporáneos y que a la larga se concretaría en la victoria de Eduardo Frei Montalva. Por otro, la definición de una representación del comunismo nacional y sus organizaciones en la cual se subrayó muchas veces de forma hiperbólica su capacidad de acción y el carácter nocivo de sus formulaciones teórico-políticas. Nuevamente a la luz de los resultados de 1964 y del acrisolamiento de la opinión católica en sus contenidos anticomunistas, esta imagen gigantomáquica del adversario logró plasmarse en la práctica política de los electores católicos, aislando con ello las opciones que desde el cristianismo se habían comprometido con la opción del FRAP.

\footnotetext{
${ }^{81}$ A. M. Stuven, La religión en la esfera pública chilena: ¿laicidad o secularización?, Santiago, Ediciones UDP, Santiago de Chile, 2014.

${ }^{82}$ FrancoisDosse, La marcha de las ideas. Historia de los intelectuales, historia intelectual, Valencia, PUV, 2007.
} 
Finalmente, en el mismo sentido de eficiencia debe destacarse el proceso de trascendentalización al que el marxismo fue sometido, logrando con ello la instalación del debate ideológico-político en el ámbito de lo metahistórico. La crítica trascendental al comunismo se realizó de forma paralela y complementaria a su dimensión contingente, elaborándose un antagonismo que permitió al pensamiento católico así construir un enemigo integral, como activar la acción política de los católicos en un nivel de determinación capaz de movilizarlos no solo en este mundo, sino también más allá.

Recibido: 16 noviembre 2015 Aceptado: 23 marzo 2016

\section{Bibliografía y Fuentes}

\section{Fuentes}

\section{Publicaciones periódicas}

La Voz, Semanario del Arzobispado de Santiago.

Revista Mensaje, publicación de la Compañía de Jesús en Chile.

Pastoral Popular, publicación elaborada por sacerdotes chilenos.

Revista Política y Espíritu, publicación del Partido Demócrata Cristiano de Chile.

\section{Libros y folletos.}

J. H. Fichter, SJ, Cambio social en Chile. Un estudio de actitudes, Santiago, Editorial Universidad Católica, 1962.

O. Millas, Los comunistas, los católicos y la libertad, Colección Realidad Americana, Editorial Austral, Santiago, 1964.

Secretariado General del Episcopado de Chile, El deber social y político en la hora presente, Santiago, 1964

G. Viviani, El progresismo cristiano o los católicos comunistas, Santiago, Ediciones Paulinas, 1962 


\section{Libros.}

H. Blumenberg, La legitimación de la Edad Moderna, Valencia, Pre-Textos, 2009.

M.A. Cabrera, Historia, Lenguaje y Teoría de la Sociedad, Valencia, Frónesis, 2001.

F. Dosse, La marcha de las ideas. Historia de los intelectuales, historia intelectual, Valencia, PUV, 2007.

T. Harmer, El gobierno de Allende y la Guerra fría interamericana, Santiago, Ediciones UDP, 2013.

T. Harmer y A. Riquelme S., Chile y la Guerra Fría global, Santiago, Instituto de Historia UC-RIL editores, 2014.

S. McGee Deutsch, Las derechas. La extrema derecha en Argentina, Brasil y Chile, 18901939, Buenos Aires, Universidad de Quilmes, 2005.

R. PattoSá Motta, Em guarda contra o “perigovermelho”: O anticomunismo no Brasil (1917-1964), Sao Paulo, Perspectiva/FAPESP, 2002.

Ch. Mouffe y E. Laclau, Hegemonia y estrategia socialista. Hacia una radicalización de la democracia, Buenos Aires, FCE, 2004.

A. Riquelme S., Rojo atardecer. El comunismo chileno entre dictadura y democracia, Santiago, CIDBA, 2009.

A. M. Stuven, La religión en la esfera pública chilena: ¿laicidad o secularización?, Santiago, Ediciones UDP, Santiago de Chile, 2014.

\section{Artículos de revistas y capítulos de libros.}

I. Bett, "Catolicismo e Cruzada e a sociabilidade anticomunista na década de 1960", en C. Rodrigues, G. Zanotto y R. CoppeCaldeira (editores), Manifestacoes do pensamento católico na América do Sul, Rio Grande do Sul, Fonte-FAPERGS, 2015.

E. Bohoslavsky y M. Vicente, "Sino el espanto". Temas, prácticas y alianzas de los anticomunismos de derecha en Argentina entre 1955 y 1966", Anuario del Instituto de Historia Argentina, Buenos Aires, 14, 2014

H.E. Bodeker, "Sobre el perfil metodológico de la historia conceptual", Historia y Grafía, 32, México, 2009. 
M. Broquetas, "Los frentes del anticomunismo. Las derechas en el Uruguay de los tempranos sesenta", Contemporánea, 3/3, Montevideo, 2012.

G. Bucheli, "Organizaciones "demócratas" y radicalización anticomunista en Uruguay, 1959-1962”, Contemporánea, 3/3, Montevideo, 2012.

M. Casals, "Chile en la encrucijada". Anticomunismo y propaganda en la "campaña del terror" de las elecciones presidenciales de 1964", en TanyaHarmer y Alfredo Riquelme S. (editores), Chile y la Guerra Fría global, Santiago, Instituto de Historia UC-RIL editores, 2014.

M. Fernández L., "Las vías de la esperanza: compromiso político y debate conceptual en el pensamiento católico chileno. Condiciones de posibilidad para Cristianos por el Socialismo", en C. Rodrigues, G. Zanotto y R. CoppeCaldeira (editores), Manifestacoes do pensamento católico na América do Sul, Rio Grande do Sul, Fonte-FAPERGS, 2015.

R. Koselleck “Introducción al Diccionario Histórico de conceptos político-sociales básicos en lengua alemana", Anthropos, 223, Barcelona, 1999.

M. M. Pacheco, “¡Cristianismo sí, Comunismo no!. Anticomunismo eclesiástico en México", Estudios de Historia Moderna y Contemporánea de México, 24/2, México, 2002.

J. Rojas F., “Anticomunismo a la chilena: el caso de James Bond en el cómic, 1959-1971”, Revista Izquierdas, 24, 2015.

E. Scirica, "Introducción Dossier Comunistas y anticomunistas en la Argentina. Agrupaciones, redes e iniciativas políticas y culturales en el marco de la Guerra Fría en América Latina (circa 1960)", Anuario del Instituto de Historia Argentina, 14, Buenos Aires, 2014.

\section{Tesis}

Marcelo Casals A., Anticomunismo, política e ideología en Chile. La Larga Duración de la "Campaña del Terror" de 1964, Tesis para optar al grado de Magíster en Historia, Santiago, PUC, 2012.

\section{Documentos digitales}

Carta Pastoral La Iglesia y el problema del Campesinado Chileno, en http://documentos.iglesia.cl/conf/doc_pdf.php?mod=documentos_sini\&id=968 